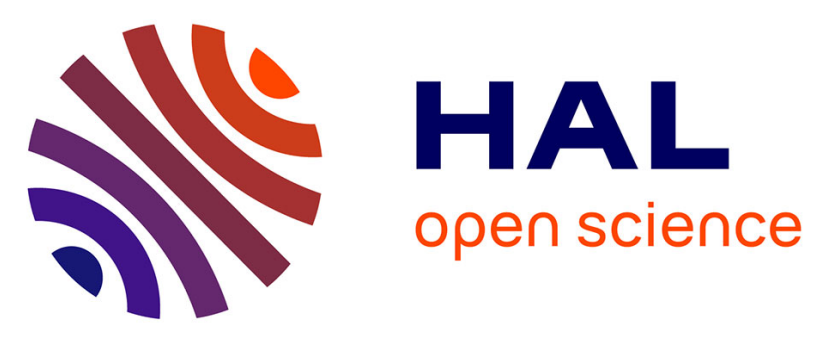

\title{
Thermal maturity of the Upper Triassic-Middle Jurassic Shemshak Group (Alborz Range, Northern Iran) based on organic petrography, geochemistry and basin modelling: implications for source rock evaluation and petroleum exploration.
}

\author{
Ali Shekarifard, François Baudin, Kazem Seyed-Emami, Johann Schnyder, \\ Fatima Laggoun-Défarge, Armelle Riboulleau, Marie-Françoise Brunet, \\ Alireza Shahidi
}

\section{To cite this version:}

Ali Shekarifard, François Baudin, Kazem Seyed-Emami, Johann Schnyder, Fatima Laggoun-Défarge, et al.. Thermal maturity of the Upper Triassic-Middle Jurassic Shemshak Group (Alborz Range, Northern Iran) based on organic petrography, geochemistry and basin modelling: implications for source rock evaluation and petroleum exploration.. Geological Magazine, 2012, 149, pp.19-38. 10.1017/S0016756811000161 . insu-00420242

\section{HAL Id: insu-00420242 \\ https://hal-insu.archives-ouvertes.fr/insu-00420242}

Submitted on 29 Sep 2009

HAL is a multi-disciplinary open access archive for the deposit and dissemination of scientific research documents, whether they are published or not. The documents may come from teaching and research institutions in France or abroad, or from public or private research centers.
L'archive ouverte pluridisciplinaire HAL, est destinée au dépôt et à la diffusion de documents scientifiques de niveau recherche, publiés ou non, émanant des établissements d'enseignement et de recherche français ou étrangers, des laboratoires publics ou privés. 


\title{
Thermal maturity of the Upper Triassic-Middle Jurassic Shemshak Group (Alborz Range, Northern Iran)
}

\section{based on organic petrography, geochemistry and basin modelling: implications for source rock evaluation and petroleum exploration}

\author{
Ali Shekarifard ${ }^{1,2}$, François Baudin ${ }^{1 *}$, Kazem Seyed-Emami ${ }^{2}$, \\ Johann Schnyder ${ }^{1}$, Fatima Laggoun-Défarge ${ }^{3}$, Armelle Riboulleau ${ }^{4}$, \\ Marie-Françoise Brunet ${ }^{1}$, Alireza Shahidi ${ }^{1,5}$
}

${ }^{1}$ UPMC-Univ. Paris06 et CNRS, UMR 7193 ISTeP, Equipe Evolution et Modélisation des Bassins Sédimentaires, case 117, 4, pl. Jussieu, F-75252 Paris cedex 05, France.

${ }^{2}$ University College of Engineering, School of Mining Engineering, University of Tehran, Tehran, Iran.

${ }^{3}$ Université d'Orléans et CNRS, UMR 6113 ISTO, 1A rue de la Férollerie, 45071 Orléans cedex 2, France.

${ }^{4}$ Université Lille 1 et CNRS, UMR 8157 Géosystèmes, bâtiment SN5, 59655 Villeneuve d'Ascq cedex, France.

${ }^{5}$ Geological Survey of Iran, Azadi square, Meraj av., 13185-1494 Tehran, Iran.

\footnotetext{
* Corresponding author: francois.baudin@upmc.fr
}

\begin{abstract}
Organic petrography and geochemical analyses have been carried out on the shales, carbonaceous shales and coals of the Shemshak Group (Upper Triassic-Middle Jurassic) from fifteen localities along the Alborz Range of Northern Iran. Organic matter (OM) has been investigated using Rock-Eval pyrolysis, elemental analysis of kerogen, vitrinite reflectance (VRr) and Thermal Alteration Index (TAI).

Reflectance of autochthonous vitrinite varies from 0.6 to $2.2 \%$ indicating thermally early mature to over mature $\mathrm{OM}$ in the Shemshak Group, in agreement with other maturity parameters used. The shales of the Shemshak Group are characterized by poor to moderate residual organic carbon contents $(0.25$ to $8.5 \%)$ and the presence of hydrogen-depleted OM, predominantly as a consequence of petroleum generation and of oxidation of OM. According to light-reflected microscopy results vitrinite/vitrinite-like macerals are dominant in the kerogens concentrated from the shaly facies. The coals and carbonaceous shales of the Shemshak Group show a wide range in organic carbon concentration (3.5 to $88.6 \%$ ) and
\end{abstract}


composition (inertinite- and vitrinite-rich types), and thereby different petroleum potentials. Among the studied sections only the coals and carbonaceous shales of the Hive locality show good residual petroleum potential and may still generate oil.

Thermal modelling results suggest that low to moderate paleo-heat flow, ranging from 47 to $79 \mathrm{~mW} \cdot \mathrm{m}^{-2}$ (57 mW.m ${ }^{-2}$ on average), affected the Central-Eastern Alborz. The maximum temperature which induced OM maturation of the Shemshak Group seems to be related to its deep burial rather than to a very strong heat flow related to an uppermost Triassic-Liassic rifting. The interval of petroleum generation in the most deeply buried part of the Shemshak Group (i.e., Tazareh section) corresponds to Late Jurassic-Early Cretaceous times.

Exhumation of the Alborz Range during Late Neogene time, especially along the axis of the Central-Eastern Alborz, where maxima of $\mathrm{VRr}$ values are recorded, probably destroyed possible petroleum accumulations. However on the northern flank of the Central-Eastern Alborz, preservation of petroleum accumulations may be better. The northern part of the basin therefore seems the best target for petroleum exploration.

Keywords: Thermal maturity; Organic petrography; Organic geochemistry; Basin modelling; Triassic-Jurassic; Shemshak Group; Alborz basin; Iran 


\section{Introduction}

After its detachment from Gondwana in Permian time, the Iran plate, as the central part of the Cimmerian continent (Sengör, 1990), moved northward and finally collided with Eurasia during Late Triassic, thereby closing the Palaeo-Tethys (Ricou, 1996; Dercourt et al., 1993; 2000; Stampfli et al., 2001; Kazmin, \& Tikhonova., 2005). The resulting EoCimmerian orogeny formed an E-W mountain belt, the so-called Cimmerides (Sengör, 1990; Sengör et al., 1998). The Alborz Range of Northern Iran itself results from the collision of Arabia with Eurasia during the Neogene which caused uplift, folding and faulting (Stöcklin, 1974; Alavi, 1996; Zanchi et al., 2006; Guest et al., 2006, 2007). The thick siliciclasticdominated Shemshak Group (Upper Triassic to Middle Bajocian), with thicknesses up to $4000 \mathrm{~m}$, is widely distributed in the Alborz (Fig. 1).

Commonly the Shemshak Group is regarded as the product of the erosion of the Cimmerides, deposited in a foreland basin (Assereto, 1966; Seyed-Emami and Alavi-Naini, 1990; Alavi, 1996; Seyed-Emami 2003). Wilmsen et al. (2007) and Fürsich et al. (2009) consider the Shemshak Group as the result of syn- and post-collisional processes of the EoCimmerian orogeny. According to these authors, the Shemshak Group represents an underfilled to overfilled foreland basin, followed by an extensional phase from the Toarcian to Bajocian times, resulting from the onset of the Neo-Tethyan back-arc rifting. The midBajocian (Mid-Cimmerian) event which usually marks the top of the Shemshak Group may represent the break-up unconformity of this rifting event. However, Brunet et al. (2007) and Shahidi (2008) interpret the Late Triassic-Early Jurassic tectonic subsidence which affected the Central Alborz domain as the main phase of crustal thinning (= rifting) of the South Caspian Basin and therefore the Alborz Range is regarded as its continental margin which is now inverted. The Mid-Bajocian break-up is considered by these authors as the beginning of thermal subsidence on the margin of the Alborz and the oceanisation of the South Caspian Basin.

Rift related-basins show higher heat flow values $\left(90-110 \mathrm{~mW} . \mathrm{m}^{-2}\right)$ than foreland basins (40-80 mW.m ${ }^{-2}$; Allen and Allen, 2005). Thus reconstruction of paleo-heat flow using thermal modelling may be a useful approach for a better understanding of the Shemshak Basin tectonic setting.

In the present study we discuss the geochemical and petrographical characteristics of organic matter $(\mathrm{OM})$ of the shaly and coaly sediments from the Shemshak Group of Northern Iran using microscopical observations and measurements as well as organic geochemical 
analyses. In particular, one of our aims was to present the regional thermal maturity pattern of the Shemshak Group in the Alborz based on vitrinite reflectance data. Vitrinite reflectance is one of the most reliable methods which is widely used as indicator of thermal maturity of a given basin (Tissot and Welte, 1984; Baudin et al., 1994; Hunt, 1995; Taylor et al., 1998). Additionally, thermal maturity and burial history of the Shemshak Group was modelled at four localities (pseudo-wells) using the commercial software Genex (Beicip-Franlab, 1995) to handle temperature, maturity, petroleum expulsion as well as paleo-heat flow of the basin through geological times. A subordinate goal of this study is to discuss the residual petroleum potential of the Shemshak Group and to propose guidelines for petroleum exploration in the future.

\section{Description of the Shemshak Group and its organic-rich units}

The Shemshak Group consists almost exclusively of fine- to coarse-grained siliciclastic sediments that are accompanied by numerous coal seams and carbonaceous shales at different stratigraphic levels. Its depositional palaeoenvironment includes fluvial, swamp and lake systems, as well as shallow to deeper marine environments with local oxygen-deficient conditions leading to the deposition of organic carbon-rich sediments (Stampfli, 1978; Rad, 1982, 1986; Baudin and Téhérani, 1991; Fürsich et al., 2005; Seyed-Emami et al., 2006; Shekarifard et al., 2009; Fig. 2).

Organic carbon-rich sediments of the Shemshak Group have been classified into three different units including Upper-Triassic shales (UTS), Toarcian-Aalenian shales (TAS) and coals/carbonaceous shales (CCS). The two former units occur in the lower and upper part of the Shemshak Group, respectively, whereas the CCS units occur at different stratigraphic levels of the Shemshak Group from the base to the top. The UTS unit corresponds to the Ekrasar and Laleband Formations in the Northern Alborz and to the Shahmirzad Formation in the Central-Eastern Alborz (Fig. 2). The TAS unit belongs to the Fillzamin and Shirindasht Formations in the Southern-Central Alborz, whereas it is not exposed in the Northern Alborz due to lateral changes of facies (Fig. 2). The CCS units occur in the Kalariz, Javaherdeh, Alasht and Dansirit formations (Fürsich et al., 2009; Fig. 2).

In a previous study eleven different sites (sections) of the Shemshak Group have been sampled and studied (Shekarifard et al., 2009). In the present study, four new sites in Eastern (Jajarm), Central (Shemshak and Hive) and Western Alborz (Maragheh) have been sampled and studied (Fig. 1). The collected samples from the Jajarm, Shemshak (site of the type 
section) and Maragheh belong to the UTS and TAS units (Fig. 2). At Hive several samples from coals and carbonaceous shales have been taken from the lower part of the Shemshak Group. This may correspond to the Kalariz Formation (Fig. 2).

\section{2.a. Upper Triassic shales (UTS)}

In the Northern Alborz the UTS corresponds largely to the Ekrasar Formation (Norian) at the base of the Shemshak Group (Bragin et al., 1976; Repin, 1987; Fürsich et al. 2009; Seyed-Emami et al., 2009). The Ekrasar Formation, with thicknesses up to $1000 \mathrm{~m}$, is mostly distributed along the Northern Alborz. It consists largely of monotonous, greenish grey to black shales, locally with some pyrite-rich levels. At Ekrasar and Galanderud, the Ekrasar Formation starts with intercalations of limestone beds with marine fossils (bivalves, ammonoids). Its boundary with the underlying Elikah Formation is sharp but conformable (Fürsich et al., 2009), whereas at Paland the boundary is gradational (Aghanabati et al., 2002). Here the Ekrasar Formation follows apparently conformably the middle Triassic carbonates and is composed of homogeneous black shales, sometimes rich in pyrite, especially in the basal part of the formation. Some dinoflagellate cysts have been observed at some levels of the black shales indicating marine conditions (Ghasemi-Nejad et al. 2004).

According to sedimentological and palynological evidence, the Ekrasar Formation was deposited in a marine basin (Ghasemi-Nejad et al., 2004; Fürsich et al. 2009) under suboxic to anoxic conditions. The black shales are locally enriched in organic carbon and are thermally over-mature (Shekarifard et al., 2009).

In the Northern Alborz, the Ekrasar Formation is followed by the Laleband Formation (Upper Norian-Rhaetian; Fig. 2). The Laleband Formation is up to $435 \mathrm{~m}$ thick (Bragin et al., 1976) and is mostly composed of an alternation of sandstones and dark shales, without any evidence of trace fossils. The transition of the Laleband Formation with the Ekrasar Formation is gradational, whereas its contact with the overlaying coal-bearing Kalariz Formation is sharp. The Laleband Formation represents turbiditic sediments of prodelta setting (Fürsich et al., 2009), and indicates infilling and shallowing of the deep marine basin.

In the Southern-Central Alborz, the basal part of the Shemshak Group corresponds to the Shahmirzad Formation (Norian-Rhaetian; Fig. 2). The Shahmirzad Formation overlies the karstified carbonates of the Elikah Formation with a sharp unconformity and is gradually overlain by the Kalariz Formation. At Tazareh it has a thickness of about $1250 \mathrm{~m}$ and consists mostly of dark shales and sandstones, with some carbonate layers and much volcanoclastics 
at the base, being deposited under fluvial, lacustrine to marginal marine settings (Fürsich et al., 2009). At Jajarm the basal part of the Shahmirzad Formation is characterized by an alternation of black shales and sandstones. The black shales are locally enriched in pyrite.

\section{2.b. Toarcian-Aalenian shales (TAS)}

The TAS unit corresponds largely to the Shirindasht and Fillzamin formations (Fürsich et al, 2009; Fig. 2). The Toarcian-early Aalenian Shirindasht Formation has a thickness of $550 \mathrm{~m}$ and is generally characterized by alternation of bioturbated grey to olive shales and fine-grained sandstones. The sandstones exhibit planar lamination, ripple bedding and hummocky cross-stratification. The basal part of the formation is a sandstone-dominated facies, and there is a gradual decrease in grain size towards the top. The occurrence of parallel and hummocky structures, marine fauna and trace fossils indicate storm-dominated shelf facies. It is gradually overlain by the Fillzamin Formation (Fürsich et al., 2005; 2009).

The Fillzamin Formation (Aalenian-early Bajocian) consists of thick, monotonous, dark-grey to greenish and highly bioturbated shales with occasional fossiliferous concretions. It reaches a thickness of up to $680 \mathrm{~m}$ at Tazareh section and is overlain by the Dansirit Formation. The presence of marine palynomorphs (e.g. acritarchs and dinoflagellate cysts), ammonoids and the relative decrease in grain size from the Shirindasht to Fillzamin Formation indicate a deepening of the basin (Fürsich et al., 2005, 2009; Shekarifard et al., 2009). Low mean organic carbon contents are associated to these fully marine and probably oxic sediments of the TAS unit (Shekarifard et al., 2009). At Shemshak type-locality, the Fillzamin Formation is lithologically different from the other localities and is characterized by an alternation of dark shales and sandstones.

\section{2.c. Coal and Carbonaceous shales (CCS)}

The Kalariz and Alasht formations are the main host rocks for coal deposits in the Alborz Range (Fig. 2). They are mainly composed of silty-clay sediments and fine-grained sandstones with numerous intercalations of coal and carbonaceous shales, representing fluvial, swamp and lake environments (Fürsich et al., 2009). The partly corresponding Javaherdeh Formation is only developed in the northern part of the Alborz. It is a thick alluvial fan deposit (up to $1000 \mathrm{~m}$ and more) consisting largely of polymictic conglomerates and sandstones. Occasionally there are intercalations of argillaceous silt and carbonaceous shales within the Javaherdeh Formation. The Dansirit Formation shows more marine 
influence and represents delta plain to marginal marine deposits. It consists mainly of sandstones with some intercalations of siltstones, carbonaceous shales and coal seams (Fürsich et al., 2009).

\section{Material and methods}

A total of 359 samples (62 from cores and 297 from natural outcrops) have been investigated for evaluation of petroleum-generation potential and thermal maturity of the entire Shemshak Group. Compared to previously published data (Shekarifard et al., 2009), 110 new samples have been collected from the new sites, including one shallow drilling core. Core samples belong to the Shahmirzad Formation in the Jajarm section. 9 coal and carbonaceous shale samples were collected from the Hive locality.

Qualitative palynofacies studies were performed on 49 samples using both transmitted and incident UV light microscopy. Organic petrography observations have been performed on kerogen concentrates and coals from the Shemshak Group using reflected white and UV light microscopy. Measurements of vitrinite reflectance were made on 37 samples including densimetric concentrates and polished blocks of the kerogen concentrates and coal using a Leica DMR-XP apparatus. These measurements were carried out on 50 to 131 vitrinite particles for each sample using a monochromatic $(546 \mathrm{~nm})$ white light with a $\times 50$ oil immersion objective, following the procedures described in Taylor et al (1998).

Petroleum source rock characterizations of the samples were carried out using RockEval OSA and RE6 instruments (Espitalié et al. 1985a, 1985b, 1986; Lafargue et al., 1998; Béhar et al., 2001). Standard notations are used: $S_{1}$ (free hydrocarbons) and $S_{2}$ (pyrolyzable hydrocarbons) in mg hydrocarbons (HC) per g of rock; Tmax is expressed in ${ }^{\circ} \mathrm{C}$; total organic carbon (TOC) content in weight $\%$, Hydrogen Index $\left(\mathrm{HI}=\mathrm{S}_{2} \times 100 / \mathrm{TOC}\right)$ in mg HC per $\mathrm{g}$ of TOC, Oxygen Index $\left(\mathrm{OI}=\mathrm{S}_{3} \times 100 / \mathrm{TOC}\right)$ in $\mathrm{mg} \mathrm{CO}_{2}$ per $\mathrm{g}$ of TOC, Genetic potential $\left(\mathrm{S}_{1}+\mathrm{S}_{2}\right)$ in $\mathrm{mg} \mathrm{HC}$ per $\mathrm{g}$ of rock and Production Index $\left(\mathrm{PI}=\mathrm{S}_{1} /\left(\mathrm{S}_{1}+\mathrm{S}_{2}\right)\right.$.

Total carbon content was determined using an elemental analyser LECO IR 212. As this apparatus burns rock up to $1100{ }^{\circ} \mathrm{C}$, the determination of total carbon is better compared to those calculated by the means of Rock-Eval pyrolysis, especially for carbon-rich (coals) samples. Calcium carbonate content of the selected samples was determined by gas volumetric analysis using a carbonate bomb. Owing to very low (mean $\mathrm{CaCO}_{3}<7 \%$ ) or lack of carbonates in these sediments, the results of LECO are considered as total organic carbon content and the hydrogen index values are calculated using LECO results.. 
Elemental analysis of 33 kerogen concentrates and some coals were performed with a Flash EA 1112 Thermo CHNSO elemental analyser. The CHNS- and O-content are determined by two distinct experiments. For CHNS analysis, 1.5 to $2 \mathrm{mg}$ of kerogen concentrates are pyrolysed by flash combustion at $1800^{\circ} \mathrm{C}, \mathrm{V}_{2} \mathrm{O}_{5}$ being used as a fusing agent. The produced gas is then separated within a chromatographic column and finally detected in a catharometer. Bis(5-tert-butyl-benzoxazol-2-yl)thiophene (BBOT) was used as standard. The oxygen content is measured on the same amount of kerogen by a pyrolysis at $1060^{\circ} \mathrm{C}$ in an $\mathrm{He}$ atmosphere. The $\mathrm{CO}_{2}$ then produced is detected as previously. Benzoic acid was used as standard.

Timing of maturation and petroleum generation was reconstructed by means of the Genex4 1D computer modelling program of Beicip-Franlab, France. Input parameters for modelling include lithology of strata, thickness, age, hiatus and heat flow. Maturity modelling was calibrated by changing the paleo-heat flow in order to fit the measured vitrinite reflectance values to calculated values.

\section{Analytical results and interpretation}

\section{4.a. Organic matter characterization}

4.a.1. Rock-Eval pyrolysis and TOC content

Bulk organic geochemical characteristics of the Shemshak Group in each of the studied sections are summarized in Tables 1, 2 and 3 for the UTS, TAS and CCS units, respectively. The TOC content of the shaly facies from the UTS unit ranges from 0.25 to $8.5 \%$ (Tab. 1). The TAS unit shows lower TOC values with an average of $0.6 \%$ and a maximum of $1.65 \%$ (Tab. 2). The dark shales of the TAS unit at Shemshak type-locality, however, show slightly higher values of organic carbon (average: $1 \%$ ), which is in agreement with previous data obtained on the same locality by Baudin and Téhérani (1991). The TOC content of the shales of TAS unit at Shahmirzad is the lowest ( $0.55 \%$ on average). Samples from the CCS units show a wider range in TOC, between 3.5 and $88.6 \%$ (Tab. 3), due to the occurrence of coaly facies in these shales.

Because many samples yield no or very little hydrocarbons $(<0.1 \mathrm{mg} / \mathrm{g}$ rock $)$ during pyrolysis, interpretable Hydrogen Index (HI) values are scarce. Only one fourth of the 359 samples display reliable HI values. They are generally very low to moderate and the HI-Tmax diagram indicates a mixture of Type IV (altered) and Type III (terrestrial) kerogens (Fig.3). 
The maxima of $\mathrm{HI}$ values (100 to $190 \mathrm{mg} \mathrm{HC/g}$ TOC) correspond to the coals and carbonaceous shales of the Shemshak Group at Hive and Damavand localities (Tab. 3).

Very low OI values of the Hive samples $\left(<13 \mathrm{mg} \mathrm{CO}_{2} / \mathrm{g}\right.$ TOC) are attributed to the original composition (probably hydrogen-rich and oxygen-poor coals) and to the high thermal maturity of the coals (see Section 4.b), because the samples have reached nearly the end of the oil window for Type III kerogen (Gentzis and Goodarzi, 1994; Mukhopadhyay et al., 1995; Iglesias et al., 2001). The HI-Tmax diagram shows that all samples of the Hive are Type III kerogen (Fig. 3). The coals of the Hive area show rather high genetic potential (average: $85 \mathrm{mgHC} / \mathrm{g}$; Tab. 3). $\mathrm{S}_{1}$ values (up to $5 \mathrm{mg} \mathrm{HC} / \mathrm{g}$ rock) and $\mathrm{S}_{2}$ values (up to $147 \mathrm{mg}$ $\mathrm{HC} / \mathrm{g}$ rock) indicate the presence of both free hydrocarbons and a remaining petroleum potential in spite of their level of thermal maturity (Littke and Leythaeuser, 1993).

\section{4.a.2 Elemental analysis of kerogen}

Elemental analysis data (Tab. 4) shows a mass balance $(\mathrm{C}+\mathrm{H}+\mathrm{N}+\mathrm{O}+\mathrm{S}$ elements) with a maximum value of $95.5 \%$ (on average $70 \%$ ) except for some samples in which the total recovery is only $40 \%$, due to a high amount of non destroyed minerals..Elemental analysis of the selected kerogen concentrates indicates generally hydrogen-depleted $\mathrm{OM}$ in the shales of the Shemshak Group. H/C ratios of the kerogen concentrates range from 0.34 to 0.97 and 0.04 to 0.34 for $\mathrm{O} / \mathrm{C}$ ratios.

The $\mathrm{H} / \mathrm{C}$ and $\mathrm{O} / \mathrm{C}$ atomic ratios of kerogen are plotted in a Van Krevelen diagram (Fig. 4). It indicates that the samples are located in the oil and wet gas windows at catagenesis stage of Type III kerogen. This observation is globally consistent with Rock-Eval data and previous elemental analysis data on samples from the Shemshak type-locality (Baudin and Téhérani, 1991).

\section{4.a.3. Palynofacies and organic petrography}

Shaly facies

Based on the present and published (Shekarifard et al., 2009) palynofacies data, the dispersed OM in the shaly units of the Shemshak Group (UTS and TAS units) is composed predominantly of amorphous $\mathrm{OM}$ and minor to moderate amounts of higher plant debris (ligno-cellulosic debris and some sporomorphs). In the studied samples, colour of spores (the so-called Thermal Alteration Index, TAI) varies from orange to dark brown/black showing a large range in thermal maturity, in agreement with other maturity parameters used. 
At Shemshak type-locality, the Toarcian-Aalenian dark shales are characterized by the dominance of amorphous OM, low percentage of ligno-cellulosic debris, sporomorphs and occasionally marine particles (scolecodontes). Unlike the other TAS units, here the shaly facies is enriched in pyrite framboids, consistent with marine setting and oxygen-poor conditions.

Palynofacies observations of the Jajarm samples do not show any marine palynomorphs. It is characterized by a very high percentage of bright brown amorphous OM, some phytoclasts, brown cuticles and spores, occasionally very rich in pyrite. Some occurrences of amorphous OM with remaining cellular structure suggest an origin from waxy coatings (Tyson, 1995). The presence of rootlets and amorphous OM indicate, at some levels, suboxic to anoxic non-marine conditions for the basal black shales of the UTS at Jajarm section.

The terminology used to classify the dispersed OM is based on the coal maceral concept of the ICCP (1975). Kerogen observations using reflected light microscopy indicate that phytoclasts dispersed in the shaly facies of the Shemshak Group are predominantly discrete particles of vitrinite with a minor contribution of inertinite macerals. Vitrinite largely occurs as isolated particles of homogeneous, partly porous vitrinite of dark grey to bright brown colour depending on the thermal maturity level. Inertinite in the shaly parts is composed of semifusinite and inertodetrinite. Liptinite group corresponds to a few sporinite and cutinite macerals and occasionally solid bitumen.

In highly mature samples ( $\mathrm{VRr}$ greater than 2\%) vitrinite appears bright grey (Fig. 5D), whereas in less mature samples it is dark grey in colour (Figs. 5A, B and C). In addition, some occurrences of vesicular vitrinite with devolatilization vacuoles (Fig. 5D) which indicate gas expulsion from vitrinite due to high thermal maturity (Laggoun-Défarge et al., 1994), are observed. Owing the absence of magmatic activity in the vicinity of studied section, the thermal maturity level of studied samples is attributed only to deep burial.

The presence of angular to well-rounded shapes of vitrinite (Fig. 5C) suggests both autochthonous and (semi-)allochthonous origins (Littke et al., 1997; Nzoussi-Mbassani et al., 2005), in agreement with the large standard deviations obtained for VRr values (see Section 4.b). In general, autochthonous vitrinite is characterized by a darker color, and a larger size, up to $100 \mu \mathrm{m}$ (Fig. 5B). 
In the basal black shales unit of the Tazareh section a few grey cutinites and wellpreserved sporinites do not show any fluorescence reflecting a high thermal maturity degree (Fig. 5E). Some occurrences of possible granular solid pyrobitumen-like particles with orange fluorescence (Fig. 5F) in late mature samples of the Ekrasar Formation at Galanderud section confirm hydrocarbon generation from the basal shales of the Shemshak Group. Inertinite which is rarely observed appears as rounded to sub-rounded particles sometimes showing oxidation rims (Fig. 5G). Semifusinite/fusinite exhibits angular to sub-angular shapes with characteristic cellular structure (Fig. 5H). Minerals identified using reflected light include carbonate, quartz, clays and pyrite framboids. Fine-grained pyrite crystals are commonly associated with vitrinite (Fig. 5B).

\section{Coaly facies}

Homogeneous vitrinite (telocollinite and/or desmocollinite, Fig. 6A) is the dominant maceral in the studied coals from the Hive locality, with a low percentage of inertinite. Vitrinite appears grey to dark grey and is partly associated with pyrite grains. In the studied coals, micrinite (Fig. 6B), macrinite (Fig. 6C), semifusinite/fusinite (Fig. 6D) and inertodetrinite correspond to the main macerals of the inertinite group. Liptinite macerals, with the exception of bitumen, have not been identified. Although vitrinite does not fluoresce in our samples, darker bands of vitrinite or vitrinite-like components show weak red fluorescence, probably due to either higher hydrogen content or different precursor material which shows suppressed reflectance $(\mathrm{VRr}=0.9 \%)$ (Perrussel et al., 1999; Iglesias et al., 2001). Sometimes the silty matrix of coals shows the same fluorescence, probably implying adsorption of generated petroleum.

Homogeneous vitrinite is commonly characterised by numerous parallel microfractures, pores and cavities partly filled by solid bitumen (Figs. 6E, F and G). The fractures show pinch and swell structure of different size that sometimes reaches up to $200 \mu \mathrm{m}$ in length and $30 \mu \mathrm{m}$ in width (Fig. 6E). Solid bitumen infilling cracks and cavities of the coals show red fluorescence, being the result of the high level of thermal maturity (Taylor et al., 1998). Occurrence of fluorescent exsudatinite and also the presence of micrinite are evidences for oil generation from the Hive coals of the Southern Alborz (Mukhopadhyay, 1991; Gentzis and Goodarzi, 1994; Stasiuk et al., 2006).

Although numerous studies have shown that coals are moderate to poor source for liquid petroleum because of specific conditions and problems of migration, the generated 
hydrocarbons predominately migrate out as gas (Bertrand, 1989; Boreham and Powell, 1993; Littke and Leythaeuser, 1993). Concentrations of the parallel microfractures, pores and cavities are restricted to areas where the coals consist of nearly pure dark vitrinite and to isolated thick bands of dark vitrinite (Figs. 6F and G). The fractures commonly are perpendicular to vitrinite stratification where there is lamination in vitrinite. Most probably these parallel microfractures and cavities are not formed due to structural deformation and are the hydraulic microfracturing of vitrinite after overpressure due to petroleum generation or outgasing.

The lack of sporinite, cutinite and other hydrogen-rich macerals (i.e. liptinite) as well as the dominance of pure vitrinite show that the relative richness of the coals in hydrogen is related to the presence of hydrogen-rich vitrinite and/or vitrinite-like macerals. Most probably solid bitumen has been originated from this hydrogen-rich vitrinite and/or vitrinite-like material. Despite the high level of thermal maturity of the samples, the production index (PI) values are very low (less than 0.06; Tab. 3), possibly indicating petroleum migration (Hunt, 1995). As a result, it is evidenced that the Hive coals have already generated parts of their initial petroleum content but still have residual potential of oil and gas despite their level of maturity. The remaining hydrocarbon generating potential $\left(\mathrm{S}_{2}\right.$ and $\left.\mathrm{HI}\right)$, despite the high level of thermal maturity, indicates that the coals and carbonaceous shales of Hive area most probably were richer in hydrogen at lower maturity degree.

Some of the coals and carbonaceous shales of the Shahmirzad and Javaherdeh areas of the Alborz are characterized by the dominance of sub-rounded bright particles of inertinite, cemented by vitrinite (Fig. 6H). In contrast to the Hive coals that are mainly composed of pure vitrinite (vitrinite-rich coaly facies), they are very rich in oxidized particles of inertinite (inertinite-rich coaly facies). The very low hydrogen index values (maximum $21 \mathrm{mg} \mathrm{HC} / \mathrm{g}$ TOC for inertinite-rich coaly facies), high atomic $\mathrm{O} / \mathrm{C}$ ratios (up to 0.25 , Tab. 4) and the abundance of inertinite particles imply the occurrence of highly oxidized coals with very low petroleum potential.

\section{4.b. Maturity}

To assessment the maturity level of OM, only vitrinite reflectance measurements were considered as reliable maturity parameter. Most of the reflectograms show high standard deviation (up to 0.51 ) and a bimodal pattern, indicating the presence of two populations of 
vitrinite particles. The first population with lower mean vitrinite reflectance is attributed to autochthonous and the second with higher mean vitrinite reflectance to reworked particles (Nzoussi-Mbassani et al., 2005). Vitrinite reflectance reported in tables and figures correspond exclusively to reflectance measurements on autochthonous vitrinite particles.

The results of mean random vitrinite reflectance measurements (VRr) for the studied localities are given in Table 5. Vitrinite reflectance values show large variation, ranging from 0.6 to $2.2 \%$ in the studied sections, indicating thermally early mature to over-mature OM. It should be noted that the interpretable Tmax values (this study and Shekarifard et al., 2009), range from 439 to $599^{\circ} \mathrm{C}$ with an average of $491^{\circ} \mathrm{C}$ (Fig. 3), indicating also that $\mathrm{OM}$ has experienced high maturity level.

Taking the basal part of the Shemshak Group as reference, the external areas of CentralEast Alborz show lower VRr, ranging from 0.7 to $1.1 \%$, whereas the axial part shows higher values of vitrinite reflectance (1.2-2.2 VRr, Fig. 7). Regional thermal maturity pattern is clearly evidenced by vitrinite reflectance data.

\section{Input data for the modelling}

The modelling used here (Genex4 1D) is based on physical/chemical equations and on geological assumptions to reconstruct burial and thermal history of a basin, the maturity of source rocks, as well as the petroleum generation and expulsion (Tissot and Welte, 1984; Ungerer et al., 1990; Beicip-Franlab, 1995). Obviously, the results depend upon the validity of initial hypotheses. Whatsoever the uncertainties, basin modelling is an effective way of checking assumptions. 1D modelling is used here to check what final maturity is expected for the different organic-rich intervals of the Shemshak Group taking different heat-flow scenarios into account.

Several parameters are needed as input data for modelling. The choice of these parameters and the hypotheses made for modelling are briefly presented below:

\subsection{Stratigraphy of pseudo-wells.}

Due to the lack of boreholes in the studied areas of the Alborz Range the modelling was done using the sedimentary records from the outcrops. Then, four pseudo-wells were reconstructed in order to understand the controlling factors on thermal maturity of the Shemshak Group and to estimate paleo-heat flow in the Central-Eastern Alborz Range. The 
Tazareh section (section 5 on Fig. 1) was selected as a representative section. The sections of Galanderud, Jajarm and Shahmirzad (sections 9, 12 and 1 on Fig.1, respectively), chosen from the mature zone of the Central-Eastern Alborz, were also modelled. The lithostratigraphy data (thickness, age, lithology) on the Shemshak Group and overlying sediments are based mostly on the studies of Shahidi (2008) and Fürsich et al. (2009).

These four pseudo-wells are reconstructed up to their burial maximum before the inversion of the basin, which is here not reconstructed. Therefore the results are only valid if maturation is strictly related to pre-deformational events. Another important assumption is that unconformities within the studied sedimentary succession were considered as no deposition events as the eroded thickness is not constrained. Calibration of model is usually performed by changing the palaeo heat-flow or by changing assumptions on eroded thicknesses. This latter possibility was not tested here. It should be noted, however, that modelling with constant heat flow was also tested by changing possible eroded thicknesses at main unconformities (e.g. at Tazareh section). It does not allow matching vitrinite reflectance data and increase discrepancies. Absolute ages were taken from the default geological time scale given in Genex 1D (Beicip-Franlab, 1995). In absence of precise palaeobathymetric estimation for the deposition of all modelled formations, this parameter as well as sea-level variations trough time were neglected. Percentages of ten lithologies (sandstone, siltstone, shale/claystone, marls, limestone dolomite, salt, anhydrite, coal and tuff) were attributed to the different formations. The initial porosity, matrix density, matrix thermal conductivity and matrix heat capacity were adopted from the default values given in Genex 1D (BeicipFranlab, 1995). The porosity-depth relationship for decompaction correction proposed in Genex 1D was employed to model burial histories.

\subsection{Source rock data and kinetic parameters}

The characteristics of source rocks (quantity and quality of the organic matter) used for modelling derived from the geochemical and petrographical results described above. Both UTS and TAS shaly units were modelled with $1 \%$ TOC and a Type II kerogen. Although the present-day characteristics of residual organic matter in the Shemshak Group indicates rather Type III and IV organic matter, a Type II kerogen was chosen for modelling, assuming that the initial organic matter was probably marine, as suggested by sedimentological and palynological evidence (Shekarifard et al., 2009). CCS unit was modelled with $3 \%$ TOC (6\% for Shahmirzad section) and a Type III kerogen. The thickness of the organic-rich levels in 
CCS unit is only tenth of the total thickness in the modelled pseudo-wells because of the discrete distribution of these facies in studied sections.

Genex 1D chemical kinetic model includes both primary cracking (i.e. transformation of kerogen into liquid hydrocarbons) and secondary cracking (i.e. progressive degradation of oil into gas and carbon residue). Up to five fractions $\left(\mathrm{C}_{15+}, \mathrm{C}_{6}-\mathrm{C}_{15}, \mathrm{C}_{2}-\mathrm{C}_{5}, \mathrm{C}_{1}\right.$ and coke) may be considered and can be modified. Default values of kinetic parameters were used.

Expulsion was considered in our modelling with $20 \%$ saturation of oil as the threshold for primary migration.

Finally, the $\mathrm{VRr}$ measurements on the sections corresponding to our four pseudowells were introduced as thermal maturity data.

\subsection{Thermal parameters}

The thermal history in a sedimentary basin is governed by (1) heat flow from the mantle, (2) the radiogenic heat produced in the crust, and (3) regional water flow. The increase in heat flow during rifting is related to the lithospheric thinning, which influences heat entering the basin from the asthenosphere. The main mode of heat transfer in sedimentary rocks is by vertical thermal conduction, determined by sediment lithology, porosity and nature of pore fluids. Convective heat flow, lateral dispersion of heat flow by conduction and anomalous heat intrusion, if moderate in size, have fewer influences and can be neglected.

In Genex 1D software, two basic assumptions for heat flow histories can be implemented: (1) steady state, a constant heat flow over time, and (2) non-steady state, a variable heat flow over time such variable heat flow through time or rift heat flow model. The rift heat flow model incorporates a higher heat flow episode during the rift phase and an exponential reduction during the post-rift phase adapted from the MacKenzie (1978) rifting model.

Several assumptions were made for our modelling: (1) the present-day surface temperature was fixed at $15{ }^{\circ} \mathrm{C}$ as boundary condition, (2) the heat flow values discussed here are given at the base of the Shemshak Group, that means the Palaeozoic sedimentary rocks below are considered as part of the "upper crust".

For our modelling, temperature was calculated using the transient heat flow model. The method to calculate temperature takes into account the thermal conductivities and heat capacities of the lithologies. 


\subsection{Heat-flow scenarios}

Both rift heat flow and constant heat flow models can be evaluated by comparing observed and modelled maturity data. A good agreement between observed and calculated $\mathrm{VRr}$ values and temperatures imply that the $1 \mathrm{D}$ model thermal history may represent that similarly experienced by the sediments in geological past. Several scenarios were tested here:

- a constant heat flow which was examined from 40 to $80 \mathrm{~mW} . \mathrm{m}^{-2}$ with a small increase (ranging from 2 to $5 \mathrm{~mW} \cdot \mathrm{m}^{-2}$ ) at each run. Such heat flow values are compatible with usual foreland basin heat-flows,

- a variable heat flow through time, with a strong increase $\left(80 \mathrm{~mW} \cdot \mathrm{m}^{-2}\right)$ during the deposition of the Shemshak Group (216 to $170 \mathrm{Ma}$ ),

- a rifting hypothesis with three scenarios, (i) a long rifting phase from 216 to 170 $\mathrm{Ma}$, (ii) a two steps rifting with extensive phases ranging from 216 to $199 \mathrm{Ma}$ and 183 to $170 \mathrm{Ma}$ in order to test the reconstruction of Brunet et al. (2007) and Shahidi (2008), and (iii) a short rifting from 183 to $170 \mathrm{Ma}$ in accordance with the scenario of Fürsich et al. (2005). A $1.45 \beta$ factor was used for these three scenarios.

\section{Thermal modelling results and interpretation}

In basin modelling when the discrepancy between the measured thermal maturity data and modelled maturity curve is small, the modelling is considered successful and therefore the subsequent results will be reliable (Yalcin, 1991; Inan et al., 1997). In addition, the paleoheat flow history of the basin can be proposed by fitting observed thermal maturity and modelled maturity curve (Sheng and Middleton, 2002; Justwan et al., 2006).

Burial geohistory of the Tazareh section indicates rapid sedimentation during the deposition of the Shemshak Group (Fig. 8). The obtained burial history is consistent with the studies of Brunet et al. (2007) and Shahidi (2008) which indicate two phases of high tectonic subsidence for the Shemshak Group in the Tazareh section, during Late Triassic and Toarcian-Aalenian to early Bajocian times. Fürsich et al. (2005) demonstrated the high sedimentation rate (up to $700 \mathrm{~m} . \mathrm{Ma}^{-1}$ ) within the Toarcian-Aalenian interval of the Shemshak Group at Tazareh. At Shahmirzad and Jajarm sections the main subsidence phase of the Shemshak Group corresponds to Middle Jurassic, whereas at Galanderud the main subsidence phase is during the Late Triassic Laleband Formation (Fig. 8). 
In order to estimate the paleo-heat flow at Tazareh we tried to match our measured vitrinite reflectance data (plus some data from Ram, 1978) and calculated thermal maturity curve. The thermal modelling at Tazareh section using the constant heat flow of $47 \mathrm{~mW} . \mathrm{m}^{-2}$ gives the best fit for the observed thermal maturity data (Fig. 9A), indicating moderate paleoheat flow at the base of the sedimentary pile during the deposition of the Shemshak Group. However, the two steps and short rifting scenarios also show good accordance with the vitrinite reflectance data. Both indicate a maximum heat-flow around $50 \mathrm{~mW} \cdot \mathrm{m}^{-2}$ during the deposition of the Shemshak Group in the Tazareh section. According to the considerable thickness of the Shemshak Group at Tazareh (4000 m), the moderate estimated heat flow (47 to $50 \mathrm{~mW} . \mathrm{m}^{-2}$ ) is certainly related to the very rapid sedimentation rate, the so-called blanketing effect.

In the Jajarm section using a heat flow of $49 \mathrm{~mW} \cdot \mathrm{m}^{-2}$, a good accordance is observed between measured vitrinite reflectance and modelled maturity curve, showing also very moderate paleo-heat flow (Fig. 9B).

At Shahmirzad section the use of a slightly greater heat flow value of $55 \mathrm{~mW} . \mathrm{m}^{-2}$ gives a good match between measured vitrinite reflectance and modelled maturity (Fig. 9C).

The Galanderud section is located in the northernmost part of the Central Alborz, close to the South Caspian Basin. According to present data the thickness of the Shemshak Group and its overlying strata is the lowest among the studied sections. In this pseudo-well the best fit between the observed vitrinite reflectance and modelled maturity is obtained using a constant heat flow of $79 \mathrm{~mW} . \mathrm{m}^{-2}$, indicating a high geothermal gradient in comparison to the other studied sections (Fig. 9D).

In conclusion, the paleo-heat flow estimated in the studied regions of the CentralEastern Alborz is moderate to high, ranging from 47 to $79 \mathrm{~mW} \cdot \mathrm{m}^{-2}\left(57 \mathrm{~mW} \cdot \mathrm{m}^{-2}\right.$ on average). This indicates a moderately hot basin for the Alborz domain especially during the deposition of the Shemshak Group.

It should be noted that because maximum burial of the Shemshak Group in all studied pseudo-wells has been reached during Late-Cretaceous/Tertiary times, therefore the heat flow during the sedimentation of the Shemshak Group is lesser than these values.

From the different obtained curves of kerogen transformation ratio (ratio of the amount of petroleum generated by primary cracking to the maximum amount that can be generated), using different heat flows and rifting scenarios, the maximum of kerogen transformation of 
the basal black shales at Tazareh is reached during a rather narrow time interval from MiddleJurassic to Early-Cretaceous (Fig. 10), nearly contemporaneous with the deposition of the Dalichai and Lar Formations. At the present day, the unit is thermally over-mature and located at the beginning of the dry-gas window, in good agreement with the observed vitrinite reflectance, Rock-Eval Tmax data and palynofacies results (Shekarifard et al., 2009). This suggests that the different heat flow scenarios have a limited effect on the timing of thermal maturation of this unit. Thus this period represents the timing of maturation for the most deeply buried part of the Shemshak Group at Tazareh section.

In the Jajarm section the main stage of petroleum formation for the basal black shales occurs in a wide period of time from Early Cretaceous to Miocene. This is certainly due to the lower thickness of the Shemshak Group and overlying beds at Jajarm.

The Shahmirzad section has experienced the lowest thermal maturity within the studied sections and so far only the basal part of the Group has just entered the oil window.

\section{Discussion}

The relationship between the mean vitrinite reflectance and Tmax values of the Shemshak Group and the thickness of the Shemshak Group and overlying sediments in the studied and modelled sections is shown on Fig. 11. It clearly indicates a concomitant increase in the mean vitrinite reflectance and Tmax values with the increasing depth of final burial of the Shemshak Group. The basal part of the Shemshak Group (Shahmirzad Formation) at Tazareh section has experienced the highest depth of burial and shows the highest mean vitrinite reflectance and Tmax value. Conversely the basal part of the Shemshak Group (Ekrasar Formation) at Galanderud, Jajarm and Shahmirzad sections was less buried and shows lower values. This represents a generally positive relationship between the burial depth and thermal maturity of the Shemshak Group in the studied regions of the Central-Eastern Alborz Range. A comparison between the Galanderud and Shahmirzad sections shows that despite a slightly larger thickness of the Shemshak Group and overlying strata, vitrinite reflectance -taken as indication of thermal maturity- is less at Shahmirzad than at Galanderud section. This evidences the impact of a greater heat flow -and therefore higher geothermal gradient- at Galanderud section. Geothermal gradient reconstructed from the modelled sections in the Alborz using the depth-reflectance graph of Bustin (1991) shows low values, approximately between 20 and $30^{\circ} \mathrm{C} / \mathrm{km}$. The greater value of geothermal gradient 
corresponds to the Galanderud section. The less steep trend for the samples of the Galanderud section is the result of higher geothermal gradient (Fig. 12).

According to the observed VRr values, the basal parts of the Shemshak Group at Paland, Parvar and Baladeh are thermally over-mature and located in the dry gas-window similar to the Tazareh section. Although confident data on the lithostratigraphy and thickness of the Shemshak Group and overlying sediments at Paland and Baladeh are not available, their high thermal maturity is most probably a consequence of deep burial and a timing of maturation for these localities similar to those modelled for the Tazareh section. The Tazareh, Paland and Baladeh sections are relatively close to each other, lying on the axis of the Central-Eastern Alborz and most probably have experienced the same geological events. The Shemshak Group at Tazareh section has the highest thickness (4000 m thick) among all studied sections, the lowest paleo-heat flow, and the highest thermal maturity among the modelled sections. This shows both the dominant effect of burial depth on the thermal maturity level as well as the importance of rapid sedimentation on the heat flow value. Most probably all the sections located in the over-mature zone along the axis of the Central-Eastern Alborz correspond to the deepest part of the Shemshak basin. In marginal parts of the Alborz such as Galanderud, Jajarm and Shahmirzad, the lower thermal maturity of the Shemshak sediments is largely related to the lesser thickness of the Shemshak Group and of the overlying strata.

Results of thermal modelling indicate that the paleo-heat flow from the Tazareh, Shahmirzad and Jajarm sections is between 47 and $55 \mathrm{~mW} \cdot \mathrm{m}^{-2}$, whereas the Galanderud section situated on the northern margin of the Alborz shows a higher value of $79 \mathrm{~mW} . \mathrm{m}^{-2}$. It indicates increasing paleo-heat flow towards the northern margin of the Central-Eastern Alborz. This high paleo-heat flow recorded at Galanderud section may be the result of the proximity to the South Caspian depression and the effect of the thermal anomaly on the margins during its opening.

Summing up, observed variations in OM maturity values of the Shemshak Group, in the Central-Eastern Alborz are mainly related to higher temperatures resulting from greater depth of burial, as well as the greater geothermal gradient for the northern part, e.g. at Galanderud section. The modelled heat flow geohistory at the base of the of studied sections shows a sharp decrease in the heat flow during the sedimentation of the Shemshak Group, due to input of considerable amounts of cold siliciclastic sediments into the basin (Fig. 13). 
During the deposition of the Dalichai and Lar formations, only the Shahmirzad Formation at Tazareh section has entered the oil window in Late Jurassic to Early Cretaceous times, while the Jajarm, Galanderud and Shahmirzad sections remained immature or early mature.

During the Late Neogene, exhumation of Alborz accompanied with inversion tectonics, the most deeply buried parts of the Shemshak Group were highly uplifted and exposed, whereas marginal parts of the Central-Eastern Alborz were less uplifted (Alavi, 1996; Allen et al., 2003; Zanchi et al., 2006; Guest et al., 2006, 2007). Maximum of subsidence and uplift in the Central-Eastern Alborz occurred along the axis of the Alborz. It should be noted that uplifting not only interrupts the generation of petroleum, but also destroys possible petroleum accumulations.

The effect of tectonic burial, due to the overthrusting and the Late Cretaceous magmatism on the maturity of the Shemshak Group, cannot, however, fully be ruled out: the north-western Alborz has experienced extensive Late Cretaceous magmatism and strong tectonics, whereas towards the east the intensity of magmatism and tectonics decreases (Alavi, 1996). This may have a possible importance at some localities in the north-western Alborz, probably at Javaherdeh and Ekrasar sections, where the Shemshak Group has been buried by thrust sheets. Conversely, the Late Neogene to Quaternary volcanism (e.g. Damavand Mountain) probably did not affect the thermal maturity of the Shemshak Group. This is indicated by Shemshak and Damavand sections, which are in the vicinity of the Damavand volcano and which do not show high maturity values.

According to our previous data (Shekarifard et al., 2009) and the present results, the basal blackish shales from the Shahmirzad, Ekrasar and Laleband Formations (UTS unit) and also some carbonaceous shales and coals (CCS unit) were the most significant effective petroleum source rocks within the Shemshak Group. Shoreface and deep-water sandstones of the Shemshak Group (Fürsich et al., 2006) probably acted as the first potential reservoirs (stratigraphical traps). The compressional phases of Late Cretaceous and Late Neogene times later created various types of structural and stratigraphic structural traps. Cenozoic successions but also Cretaceous and older strata may be regarded as important potential reservoirs.

According to the modelling results, the petroleum source rocks at the basal part of the Tazareh section, along the axis of the Alborz have generated petroleum earlier than its equivalent strata in the marginal areas as Galanderud and Jajarm. It is, however, likely that 
subsequent tectonic activity and uplifting during the Late Neogene time has destroyed possible petroleum accumulations. Therefore the axis of the Alborz has a low potential for petroleum prospectivity. On the contrary at the marginal parts of the Alborz, especially in the areas of Galanderud and Jajarm, where the Shemshak Group was less affected by the Late Alpine tectonic activities, there is a high potential for occurrence and preservation of generated petroleum. The relatively low thermal maturity observed along the margin of the Central-Eastern Alborz, especially in northern part, combined with the occurrence of gas/oil seepages and also presence of oil traces in Cretaceous rocks in drilled wells in the Caspian Sea and its coastal plains, suggests that this area may contain an active petroleum system. This area is thus the best target for oil and gas exploration in the Alborz Range of North Iran.

\section{Conclusions}

1- A multidisciplinary approach, including petrographical and geochemical methods and basin modelling, indicates a large variability of thermal maturity for the Shemshak Group along the Alborz Range, ranging from early-mature to over-mature. The large variation in OM thermal maturity is predominately a consequence of different burial histories.

2- Based on the maturity map presented, thermal maturity is high along the axis of the Central-Eastern Alborz, including Tazareh, Paland and Baladeh areas, whereas it decreases towards the external zones of the Alborz Range.

3- Thermal maturity modelling demonstrates that the major episode of maturation and petroleum generation of the Shemshak Group was associated with deep sedimentary burial ranging from the Late Jurassic to Early Cretaceous times in the central parts of the Central and Eastern Alborz, whereas in the marginal parts maturation continued until Neogene time. Therefore, the basal source rocks at Tazareh section generated petroleum earlier than its equivalent strata at the marginal areas.

4- The estimated values for the paleo-heat flow modelling from the Alborz are generally moderate, ranging from $47-55 \mathrm{~mW} \cdot \mathrm{m}^{-2}$ in the central and southern part of Alborz and to $79 \mathrm{~mW} . \mathrm{m}^{-2}$ in the northern part of Alborz. Minimum paleo-heat flow values correspond to the Tazareh section where the Shemshak Group has a maximum thickness near to $4000 \mathrm{~m}$. Moderate paleo-heat flow observed is a response to rapid sedimentation and high subsidence rate of the Shemshak Group.

5- Though our study does not allow a precise deciphering between different geodynamic scenarios during the deposition of the Shemshak Group, our results provide the 
first constraints on its history of maturation. These constraints will provide a useful basis for future numerical modelling and emphasize the need for a better understanding of the burial history of the Shemshak Group to reconstruct the timing of oil generation and expulsion. Nevertheless, our preliminary data indicate that the Shemshak Group has generated petroleum during Miocene in some parts of Alborz. These areas are of main interest for future oil prospection and should be explored carefully. 


\section{Acknowledgements}

The present study is part of the $\mathrm{PhD}$ research programme carried out between the University of Tehran (School of Mining Engineering) and the University of Paris 6, within the framework of the Middle East Basin Evolution programme (MEBE). We acknowledge financial support by the Alexander von Humboldt-Foundation (within the framework of an institutional partnership between Wurzburg and Tehran University) and MEBE Programme. We also thank Beicip-Franlab for the use of Genex software, Geological Survey of Iran (GSI) for logistic support, Marielle Hatton, Florence Savignac, Laurence Debeauvais and Léa Marie Bernard for their analytical helps. Our thanks go also to Prof. Franz Fürsich and Prof. Markus Wilmsen (Erlangen University) and Dr. M.R. Majidifard (GSI) for their help during the fieldtrips. 


\section{References}

Aghanabati, A., Saidi, A., Ghasemi Nejad, E., Ahmadzadeh Heravi, M. \& Dabiri, O. 2002. Palynostratigraphy of Upper Triassic sediments in North of Alborz Mountains, Galanderud and Paland area, Geoscience, 11, 76-91 (in Farsi).

ALAVI, M. 1996. Tectonostratigraphic synthesis and structural style of the Alborz Mountains system in northern Iran. Journal of Geodynamics, 11, 1-33.

Allen, P.A. \& Allen, J.R. 2005. Basin analysis principles and application, $2^{\text {nd }}$ ed., Blackwell Scientific Publications, 549 p.

Allen, M. B., Vincent, S. J., IAn Alsop, G., Ismail-Zadeh, A. \& Flecker, R. 2003. Late Cenozoic deformation in the South Caspian region: effects of a rigid basement block within a collision zone. Tectonophysics, 366, 223-239.

Assereto, R. 1966. The Jurassic Shemshak Formation in central Elburz (Iran). Rivista Italiana di Paleontologia e Stratigrafia, 72, 1133-1182.

Baudin, F., Monod, O., Begoüen, V., Laggoun-Defarge, F. \& Person, A. 1994. Caractérisation et diagenèse de la matière organique du Jurassique supérieur du Taurus occidental (Turquie méridionale). Reconstitution paléoenvironnementale et conséquences tectoniques. Bulletin Société géologique de France, 2, 135-145.

BAudin, F. \& TeherAni, K. 1991. Faciès organiques et maturation thermique du Lias supérieur de la Formation de Shemshak (Elbourz central, Iran). Eclogae Geologicae Helvetiae, 84, 3, 727-738.

BeICIP-Franlab, 1995. Genex Single Well (User Guide), Beicip-Franlab, 464 p.

Béhar F., Beaumont, V. \& Penteado, H.L. 2001. Rock-Eval 6 Technology: Performances and Developments. Oil \& Gas Science and Technology. Revue de l'IFP, 56, 2, 111-134.

BERTRAND, P. 1989. Microfacies and petroleum properties of coals as revealed by a study of North Sea Jurassic coals. International Journal of Coal Geology, 13, 575-595.

Boreham, C.J. \& Powell, T.G. 1993. Petroleum source rock potential of coal and associated sediments: qualitative and quantitative aspects. In Hydrocarbons from Coal (eds B.E. Law \& D.D. Rice), American Association Petroleum Geologists Studies in Geology, 38, $133-158$.

Bragin, Y., Jahanbakhsh, F., Golublev, S. \& Sadovnikov, G. 1976. Stratigraphy of the Triassic-Jurassic coal-bearing deposits of Alborz. National Iranian Steel Corporation, Tehran, NISC V/O “Technoexport”, internal report, 49 p. 
Brunet, M.-F., Shahidi, A., BARrIER, E., Muller, C. \& SAIDI, A. 2007. Geodynamics of the South Caspian Basin southern margin now inverted in Alborz and Kopet-Dagh (Northern Iran). Geophysical Research Abstracts, European Geosciences Union, Vienna, 9, 08080, http://www.cosis.net/abstracts/EGU2007/08080/EGU2007-J08080.pdf.

Bustin, R. M. 1991. Organic maturity in the Western Canada sedimentary basin, International Journal of Coal Geology, 19, 319-358.

Dercourt, J., Ricou, L.E. \& VRIELYNCK., B., 1993. Atlas Tethys Paleoenvironmental Maps, Gauthier-Villard, 307 p., 14 maps.

Dercourt, J., Gaetani, M., Vrielynck, B., Barrier, E., Biju-Duval, B., Brunet., M-F., Cadet, J.P., Crasquin, S. \& Sandulescu, M. 2000. Atlas Peri-Tethys Palaeogeographical maps, 268 p., 24 maps.

Espitalie, J., Deroo, G. \& MARQuis, F. 1985a. La pyrolyse Rock-Eval et ses applications. Partie I. Revue de l'Institut Français du Pétrole, 40, 5, 563-579.

Espitalie, J., Deroo, G. \& Marquis, F. 1985b. La pyrolyse Rock-Eval et ses applications. Partie II. Revue de l'Institut Français du Pétrole, 40, 6, 755-784.

Espitalie, J., Deroo, G. \& Marquis, F. 1986. La pyrolyse Rock-Eval et ses applications. Partie III. Revue de l'Institut Français du Pétrole, 41, 1, 73-89.

Fürsich, F.T., Wilmsen, M., Seyed-Emami, K., CeCCA, F. \& MAJidifard M. R. 2005. The Upper Shemshak Formation (Toarcian-Aalenian) of the eastern Alborz: Biota and paleoenvironments during a transgressive-regressive cycle. Facies, 51, 365-384.

FÜrSICH, F.T., WiLMSEN, M. \& SEYED-EMAMI, K. 2006. Ichnology of Lower Jurassic beach deposits in the Shemshak Formation at Shahmirzad, southeastern Alborz Mountains, Iran. Facies, 52, 599-610.

Fürsich, F.T., Wilmsen, M., Seyed-Emami, K. \& MAJIDIfard, M. R. 2009. Lithostratigraphy of the Upper Triassic-Middle Jurassic Shemshak Group of northern Iran. In South Caspian to Central Iran basins (eds M.F. Brunet, M. Wilmsen \& J.W. Granath). The Geological Society, London, Special Publications, 312, 129-160.

GENTZIS, T. \& GoodARZI, F. 1994. Reflectance suppression in some Cretaceous Coals from Alberta, Canada, In Vitrinite reflectance as a maturity parameter: application and limitations (eds P. K. Mukhopandhyay \& W.G. Dow), American Chemical Society. pp. 93-110. 
Ghasemi-Nejad, E., Aghanabati, A. \& DabiRi, O. 2004. Upper triassic dinoflagellate cysts from the base of the Shemshak Group in north of Alborz Mountains, Iran. Review of Palaeobotany and Palynology, 132, 207-217.

Guest, B., Axen, G.J., LAM, P.S. \& HassanZadeh, J. 2006. Late Cenozoic shortening in the west-central Alborz Mountains, northern Iran, by combined conjugate strike-slip and thin-skinned deformation. Geosphere, 2 (1), 35-52.

Guest, B., Guest, A. \& Axen, G. 2007. Late Tertiary tectonic evolution of northern Iran: a case for simple crustal folding. Global and Planetary Change, 58, 435-453.

HunT, J. W. 1995. Petroleum geochemistry and geology, $2^{\text {nd }}$ ed., New York, W. H. Freeman and Company. $742 \mathrm{p}$.

Iglesias, M. J., Cuesta, M J., Laggoun-Defarge, F. \& Suarez-Ruiz, I., 2001. The influence of impregnation by hydrocarbons on coal structure during its thermal evolution. Journal of Analytical and Applied Pyrolysis, 58-59, 841-871.

Inan, S., Yalcin, N.M., Guliev, I.S., Kuliev, K. \& Feizullayev, A.A. 1997. Deep petroleum occurrences in the Lower Kura Depression, South Caspian Basin, Azerbaijan: an organic geochemical and basin modeling study. Marine and Petroleum Geology, 14, $7 / 8,731-762$.

ICCP, 1975. International Handbook for Coal Petrology Glossary, $2^{\text {nd }}$ ed., CNRS, Paris, Vol. 1,2 and 3.

Justwan, H., Meisingset, I., Dahl, B. \& Isaksen, G. H. 2006. Geothermal history and petroleum generation in the Norwegian South Viking Graben revealed by pseudo-3D basin modelling. Marine and Petroleum Geology, 23, 791-819.

KAZMin, V.G. \& TiKHONOVA, N.F., 2005. Early Mesozoic marginal seas in the Black Sea and Caucasus Region: plate tectonic reconstructions. Geotectonics, 40, 3, 169-182.

Lafargue, E., Marquis, F. \& Pillot, D. 1998. Rock-Eval 6 applications in hydrocarbon exploration, production and soils contamination studies. Oil \& Gas Science and Technology-Revue de l'IFP, 53, 4, 421-437.

Laggoun-Defarge，F., Lallier-Verges， E., Suarez-Ruiz， I., Cohaut， I., Jimenez Bautista, A., Landais, P. \& Prado, J. G. 1994. Evolution of vitrinite ultrafine structures during artificial thermal maturation, In Vitrinite reflectance as a maturity parameter: application and limitations (eds P. K. Mukhopandhyay \& W.G. Dow), American Chemical Society, pp. 194-205. 
LitTKe, R., BAKer, D.R. \& RullKötTER, J. 1997. Deposition of petroleum source rocks. In Petroleum and Basin Evolution (eds D.H. Welte, B. Horsfield, B. \& D.R. Baker). Springer, Berlin, pp. 271-334.

LitTKe, R. \& Leythaeuser, D. 1993. Migration of oil and gas in coals. In Hydrocarbons from coal (eds B. E. Law, \& D. D. Rice). American Association Petroleum Geologists Studies in Geology, 38, 219-236.

MacKenZIE, D., 1978. Some remarks on the development of sedimentary basin. Earth and Planetary Science Letters, 40, 25-32.

MuKHOPADHYAY, P.K. 1991. Hydrocarbon generation from deltaic and intermontane fluviodeltaic coal and coaly shale from the Tertiary of Texas and Carboniferous of Nova Scotia. Organic Geochemistry, 17, 6, 765-783.

Mukhopadhyay, P.K., Wade, J.A. \& Kruge, M. A. 1995. Organic facies and maturation of Jurassic/Cretaceous rocks, and possible oil-source rock correlation based on pyrolysis of asphaltenes, Scotian Basin, Canada. Organic Geochemistry, 22, 1, 85-104.

Nzoussi-Mbassani, P., COPARD, Y., \& DisnaR, J. R. 2005. Vitrinite recycling: diagnostic criteria and reflectance changes during weathering and reburial. International Journal of Coal Geology., 61, 223-239.

Perrussel, B.-P., Laggoun-Défarge, F., Suarez-Ruiz, I., Jimenez, A., Iglesias, M. J. \& RoUZAUD, J.-N. 1999. About some factors affecting vitrinite reflectance suppression. In Prospects for Coal Science in the 21st Century, (eds B.Q. Li \& Z.Y. Liu), pp. 145-148. Shanxi Science \& Technology Press.

PETERS, K. E. 1986. Guidelines for evaluating petroleum source rock using programmed pyrolysis. American Association of Petroleum Geologists Bulletin, 70, 318-329.

RAD, F. K. 1982. Hydrocarbon potential of the eastern Alborz Region, NE Iran. Journal of Petroleum Geology, 4, 419-435.

RAD, F.K. 1986. A Jurassic delta in the eastern Alborz, NE Iran. Journal of Petroleum Geology, 9, 281-294.

RAM, M-H. 1978. Etude pétrographique et aperçu palynologique du charbon de Tazareh (Elbourz oriental, Iran). PhD thesis, University Paris 6-Pierre et Marie Curie, $122 \mathrm{p}$.

REPIN, Y..S. 1987. Stratigraphy and palaeogeography of coal-bearing sediments of Iran. Unpublished Report, National Iranian Steel Company 1, 1-326; 2, 1-198; 3, 37 pls., Tehran (in Farsi). 
RICOU, L.E., 1996. The plate tectonic history of the Past Tethys Ocean. In The Ocean Basins and Margins. The Tethys Ocean (eds A.E.M. Nairn, L.E. Ricou, B. Vrielynck \& J. Dercourt), 8, Plenum Press, 3-70.

SENGÖR, A . M. C. 1990. A new model for the late Paleozoic-Mesozoic tectonic evolution of Iran and implications for Oman. In The geology and tectonics of the Oman region (eds A.H.F. Robertson, M.P. Searle \& A.C. Ries), Geological Society of London, Special. Publications, 49, 797-831.

Sengör, A. M.C., Altiner, D., Cin, A., Ustaomer, T. \& Hsu, K.J. 1998. Origin and assembly of the Tethysides orogenic collage at the expense of Gondwana Land Geological Society of London, Special Publications, 37, 119-181.

SEYed-EMAMI, K. 2003. Triassic in Iran. Facies, 48, 91-106.

Seyed-Emami, K. \& Alavi Naini, M. 1990. Bajocian stage in Iran. Memoria Descriptiva

Carta Geologica Italia, 40, 215-222.

SEYED-EMAMI, K., FÜrSich F.T, WILMSEN M., MAJIDIFARD M.R. \& SHEKARIFARD A. 2009.

Upper Triassic (Norian) Cephalopods from the Ekrasar Formation (Shemshak Group)

of Northern Alborz, Iran. Riv. Ital. Paleont. Strat., 115, no 2, 189-198.

Seyed-Emami, K., FÜrsich, F. T., Wilmsen, M., Cecca, F., Majidifard M. R., Schairer, G.

$\&$ SHEKARIFARD, A. 2006. Stratigraphy and ammonite fauna of the upper Shemshak

Formation (Toarcian-Aalenian) at Tazareh, eastern Alborz, Iran. Journal of Asian

Earth Science, 28, 259-275.

SHAHIDI, A. 2008. Evolution tectinique du Nord de l'Iran (Alborz et Kopet-Dagh) depuis le Mésozoïque. PhD thesis, University Paris 6-Pierre et Marie Curie, 500 p.

SheKarifard, A., Baudin, F., Schnyder, J. \& Seyed-Emami, K. 2009. Characterization of organic matter in the fine-grained siliciclastic sediments of the Shemshak Group (Upper-Triassic to Middle Jurassic) in the Alborz Range, northern Iran. In South Caspian to Central Iran basins (eds M.F. Brunet, M. Wilmsen \& J.W. Granath). The Geological Society, London, Special Publications, 312, 161-174.

ShENG, H. \& MidDleton, M. 2002. Heat flow and thermal maturity modelling in the Northern Carnarvon Basin, North West Shelf, Australia. Marine and Petroleum Geology, 19, 1073-1088.

StAMPFLI, G. M. 1978. Etude géologique générale de l'Elbourz oriental au sud de Gonbad-eQabus (Iran NE). Unpublished Ph.D thesis, Universite Geneve, 329 pp. 
Stampfli, G., Mosar, J., Favre, P., Pillevuit A. \& Vanney, J. 2001. Permo-Mesozoic evolution of the western Tethys realm: the Neo-Tethys East Mediterranean Basin connection. Peri-Tethys Memoire 6, Peri-Tethyan Rift/Wrench Basins and Passive Margins, Mémoire. Museum national Histoire Naturelle, 186, 51-108.

Stasiuk, L.D., Goodarzi, F. \& Bagheri-SAdeghi, H. 2006. Petroloy, rank and evidence for petroleum generation, Upper Triassic to Middle Jurasssic coals, Central Alborz Region, Northern Iran. International Jounal of Coal Geology, 67, 249-258.

StÖCKLIN, J. 1974. Northern Iran: Alborz Mountains, In: Spencer, A. M., (ed.): MesozoicCenozoic orogenic belts; data for orogenic studies; Alpine-Himalayan orogens. Geological Society London, Special Publication, 4, 213-234.

SYKES, R. \& SNOWDON, L.R.. 2002. Guidelines for assessing the petroleum potential of coaly source rocks using Rock Eval pyrolysis. Organic Geochemistry. 33, 1441-1455.

Taylor, G.H., Teichmüller, M., Davis, A., Diessel, C.F.K., LittKe, R. \& Robert, P. 1998. Organic petrology. Borntraeger, Berlin-Stuttgart. 704 p.

Tissot, B. P. \& Welte, D.H. 1984. Petroleum formation and occurrence. Springer, Berlin. 699 p.

TYSON, R.V. 1995. Sedimentary organic matter: organic facies and palynofacies. Chapman \& Hall, London. 615 p.

Ungerer, P., Burrus, J., Doligez, B., Chenet, P.Y. \& Bessis, F., 1990. Basin evaluation by integrated 2D modeling of heat transfer, fluid flow, hydrocarbon generation and migration. American Association of Petroleum Geologists Bulletin, 74, 309-335.

Wilmsen, M., Fürsich, F.T., Seyed-Emami K., Majdifard, M.R. \& Taheri, J. 2007. The Cimmerian orogoney in Iran - a foreland perspective. International Symposium on Middle East Basins Evolution, C16, December, 4. 5., CNRS Paris, France.

YALCIN, M. N. 1991. Basin modeling and hydrocarbon exploration. Journal of Petroleum Science and Engineering, 5, 379-398.

Zanchi, A., Berra, F., Mattei, M., Ghassemi, M. R. \& Sabouri, J. 2006. Inversion tectonics in central Alborz, Iran. Journal of Structural Geology, 28, 2023-2037. 


\section{Caption of figures, plates and tables:}

Fig. 1. Location map showing the distribution of the Shemshak Group outcrops with the studied localities in the Alborz Range of Northern Iran.

1. Shahmirzad area; 2. Parvar area; 3. Sharif-Abad section; 4. Djam area; 5. Tazareh section;

6. Damavand area; 7. Baladeh area; 8. Paland section; 9. Galanderud section; 10. Ekrasar area; 11. Javaherdeh area; 12. Jajarm section; 13. Shemshak type section; 14. Hive area; 15. Maragheh area.

Fig. 2. Lithostratigraphy, studied sections and sampling from the Shemshak Group in the Alborz Region (modified after Fürsich et al, 2009).

1. Shahmirzad area (lower and upper Shahmirzad sections); 2. Parvar area (lower and upper Parvar sections); 3. Sharif-Abad section; 4. Djam area; 5. Tazareh section; 6. Damavand area; 7. Baladeh area; 8. Paland section; 9. Galanderud section; 10. Ekrasar area; 11. Javaherdeh area; 12. Jajarm section (lower and upper Jajarm sections); 13. Shemshak type section; 14. Hive area; 15. Maragheh area. Location of localities on fig. 1.

Fig. 3. HI-Tmax diagram for the studied samples of the Shemshak Group in the Alborz Range showing the mature to over-mature state of organic matter. Samples from Hive locality are coals and coaly facies which are clearly related to Type III kerogen whereas samples from other localities plot in the area of Type IV (altered) organic matter.

Fig. 4. Atomic $\mathrm{H} / \mathrm{C}$ ratio versus $\mathrm{O} / \mathrm{C}$ ratio (van Krevelen diagram) for the kerogens from the Shemshak Group according to the stratigraphic units (UTS, TAC and CCS). For localities and stratigraphy see figs. 1 and 2 .

Fig. 5. Optical microphotographs of dispersed OM in the samples from the Shemshak Group (incident white light): A. Dark grey vitrinite, CCS units, Damavand section. B. Vitrinite with a lot of pyrite, UTS unit, Jajarm section. C. Autochthonous vitrinite (AV) and reworked vitrinite (RV), over-mature sample, UTS unit, Tazareh section. Vitrinite appears bright brown in the high mature samples, D. Coke from vitrinite showing irregular pores resulting of gas expulsion, over-mature sample, UTS unit, Tazareh section, E. Over-mature sporinite (Sp) with the same reflectance as vitrinite (V), UTS unit, Tazareh section, F. Solid bitumen, basal 
shales of the Ekrasar Formation, Galanderud section, G. Inertinite with oxidation rims, over mature sample, UTS unit, Tazareh section. H. Semifusinite with cellular structure and pyrites framboids, mature sample, UTS unit, Jajarm section.

Fig. 6. Optical microphotographs of the selected coals from the Shemshak Group in Alborz Range, (incident white light). Images of A, B, E, F, and G belong to the Hive coals. C and D are from the Maragheh coals.

A: Homogeneous vitrinite, B: Micrinite with homogeneous vitrinite, C: Macrinite, D: Fusinite, E: Microfractures within pure homogenous vitrinite showing pinch and swell structure, F: Selected concentrations of cracks and cavities in a vitrinite-dominated part of coal, filled by solid bitumen, G: Parallel microfractures in vitrinite with disseminated pyrites. Cracks filled by solid bitumen, $\mathrm{H}$ : Dominance of oxidized particles in the coals of the Shahmirzad section.

Fig. 7. Regional thermal maturity pattern of the basal part (mainly UTS unit) of the Shemshak Group in the Central-Eastern Alborz Range based on the measured VRr values. The central part of the Central-Eastern Alborz Range shows a higher thermal maturity.

Fig. 8. Burial geohistory curves of the Shemshak Group (grey area) and overlying sediments in the studied localities of the Central-Eastern Alborz Range. Lithostratigraphy columns are from Shahidi (2008) and Fürsich et al. (2009).

Fig. 9. Thermal maturity modelling of the Shemshak Group and estimation of paleo-heat flow in the studied localities from the Central-Eastern Alborz Range. A fitting is expected between measured vitrinite reflectance values and modelled maturity curves according to both the IFP or EASY kinetic models in order to considered the result as successful. The best fits are obtained using the heat flow of $47 \mathrm{~mW} \cdot \mathrm{m}^{-2}$ at Tazareh section (A), $49 \mathrm{~mW} \cdot \mathrm{m}^{-2}$ at Jajarm section (B), $55 \mathrm{~mW} \cdot \mathrm{m}^{-2}$ at Shahmirzad section (C) and $79 \mathrm{~mW} \cdot \mathrm{m}^{-2}$ at Galanderud section (D).

Fig. 10. Transformation ratio of kerogen and the timing of maturation for the basal black shales at Tazareh section according different heat flow values. 
Fig. 11. Relationship between mean VRr, Tmax values and thickness of the Shemshak Group and overlying sediments in studied localities.

Fig. 12. Depth-VRr diagram and paleo-geothermal gradient estimated in the studied localities, indicating low-moderate geothermal gradient in the Alborz Range (diagram from Bustin, 1991).

Fig. 13. Bottom heat flow history modelled for the studied sections in the Central-Eastern Alborz Range.

Table 1. Rock-Eval pyrolysis and LECO results of the Upper Triassic Shales (UTS) unit from the Shemshak Group in the studied portions of the Alborz Range. Localities are shown in figs. 1 and 2 .

Table 2. Rock-Eval pyrolysis and LECO results of the Toarcian-Aalenian Shales (TAS) unit from the Shemshak Group in the studied portions of the Alborz Range. Localities are shown in figs. 1 and 2.

Table 3. Rock-Eval pyrolysis and LECO results of the Coal and Coaly Shales (CCS) units from the Shemshak Group in the studied portions of the Alborz Range. Localities are shown in figs. 1 and 2.

Table 4. Results of elemental analysis of kerogen concentrates from the organic carbon-rich units in the Shemshak Group (Alborz Range). Localities are shown in figs. 1 and 2.

Table 5. Range and mean vitrinite reflectance (VRr) of the Shemshak Group in the studied localities from the Alborz Range. Localities are shown in figs. 1 and 2. 


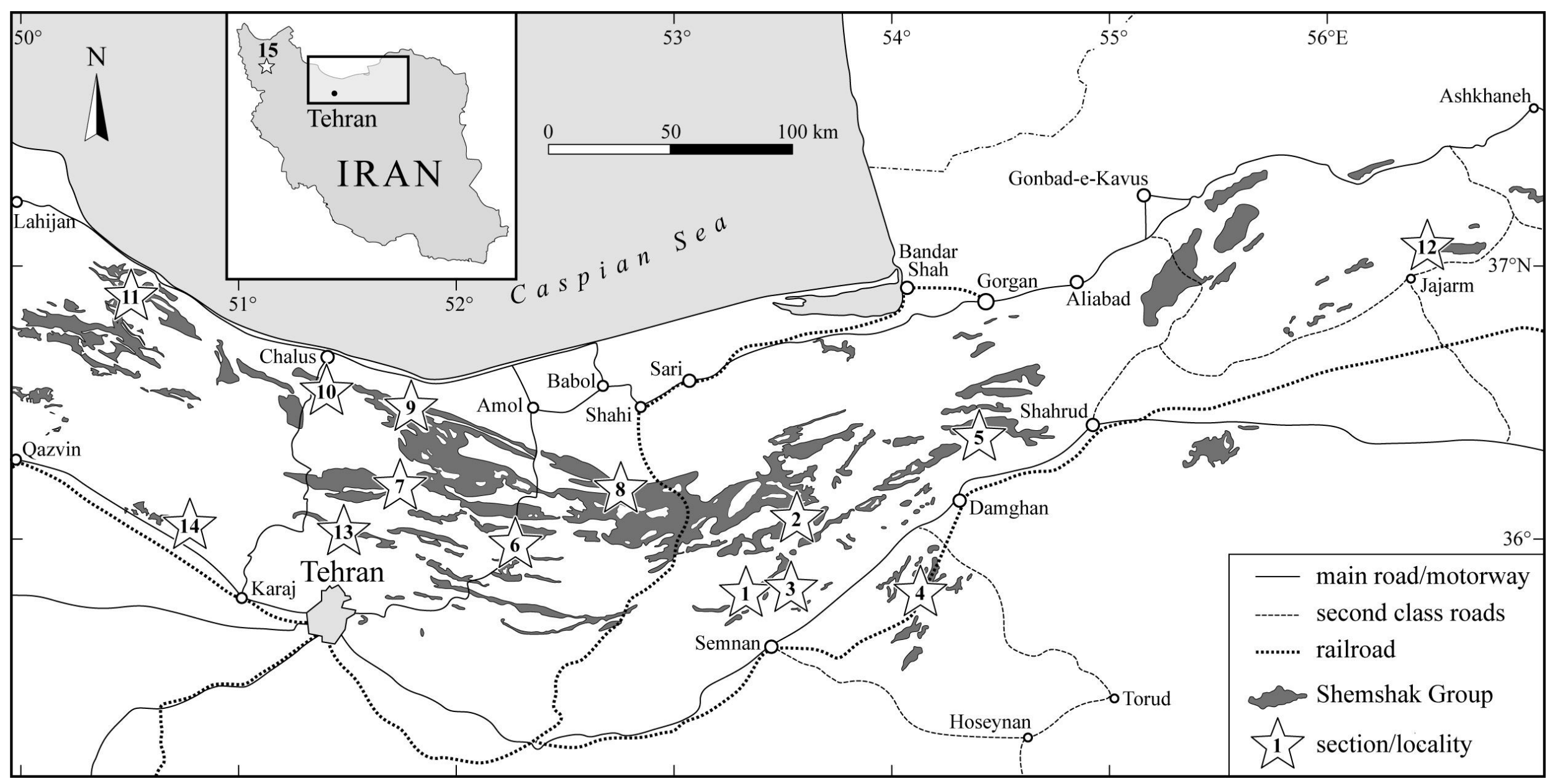

Fig. 1 


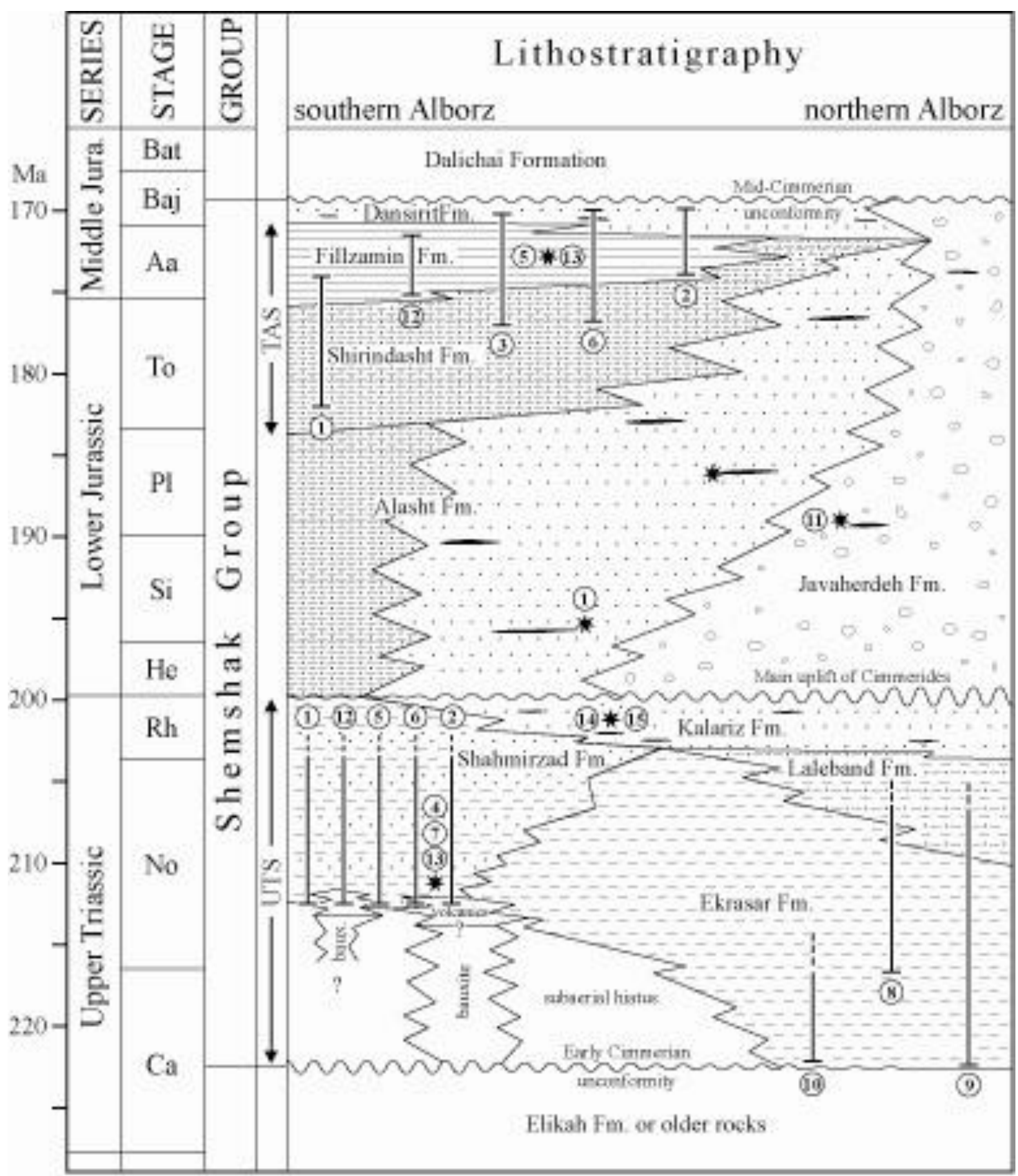

movine brakish shales
prodelta furtidites
decp marine shales

Fig. 2 


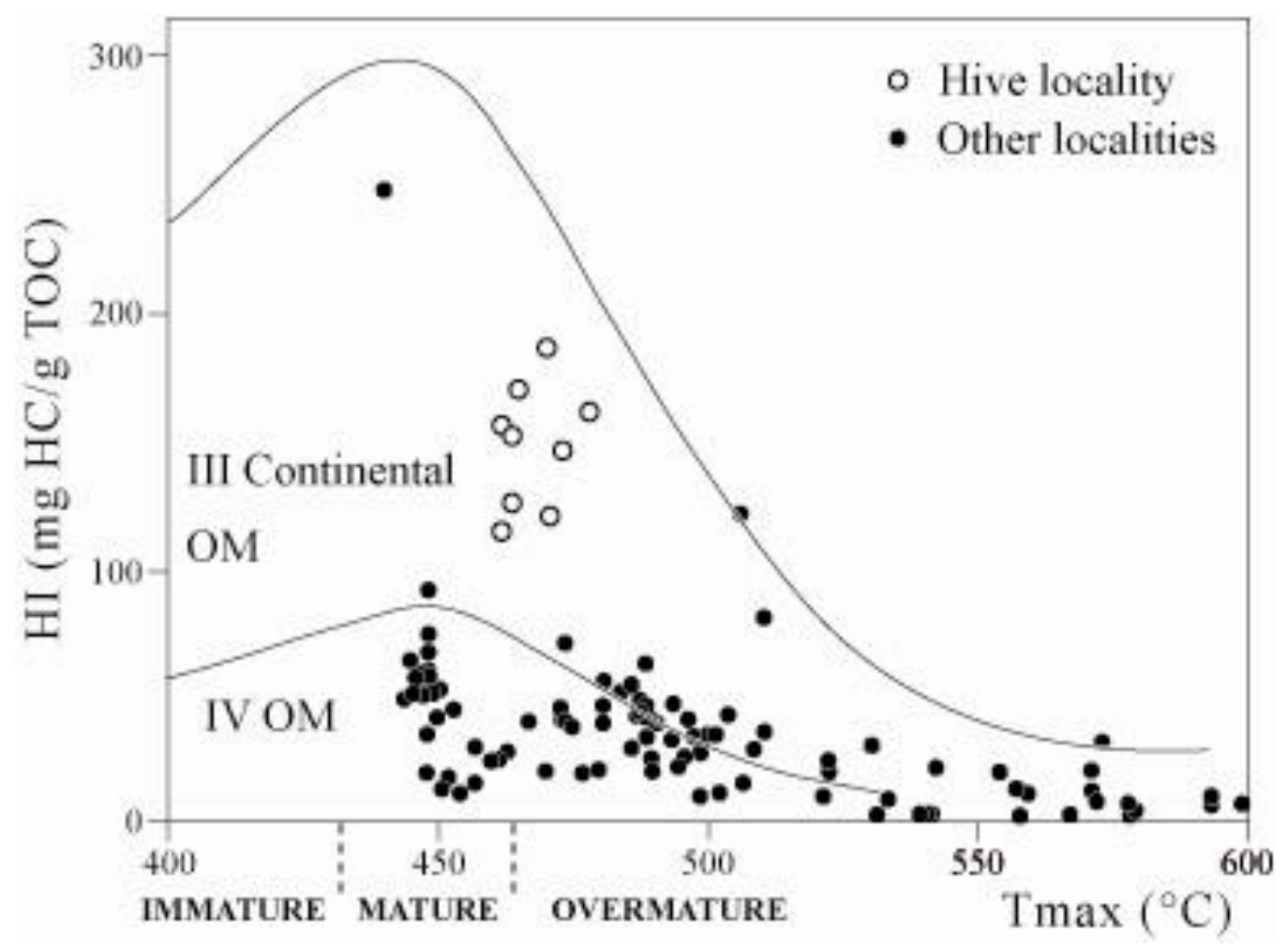

Fig.3 

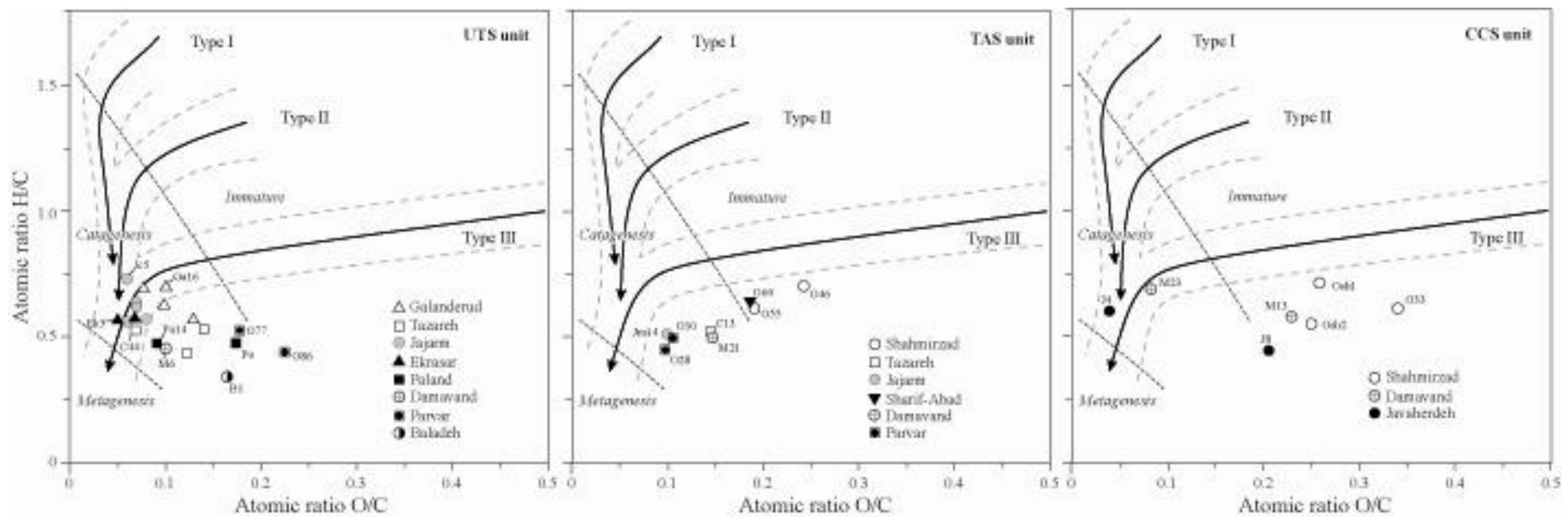

Fig. 4 

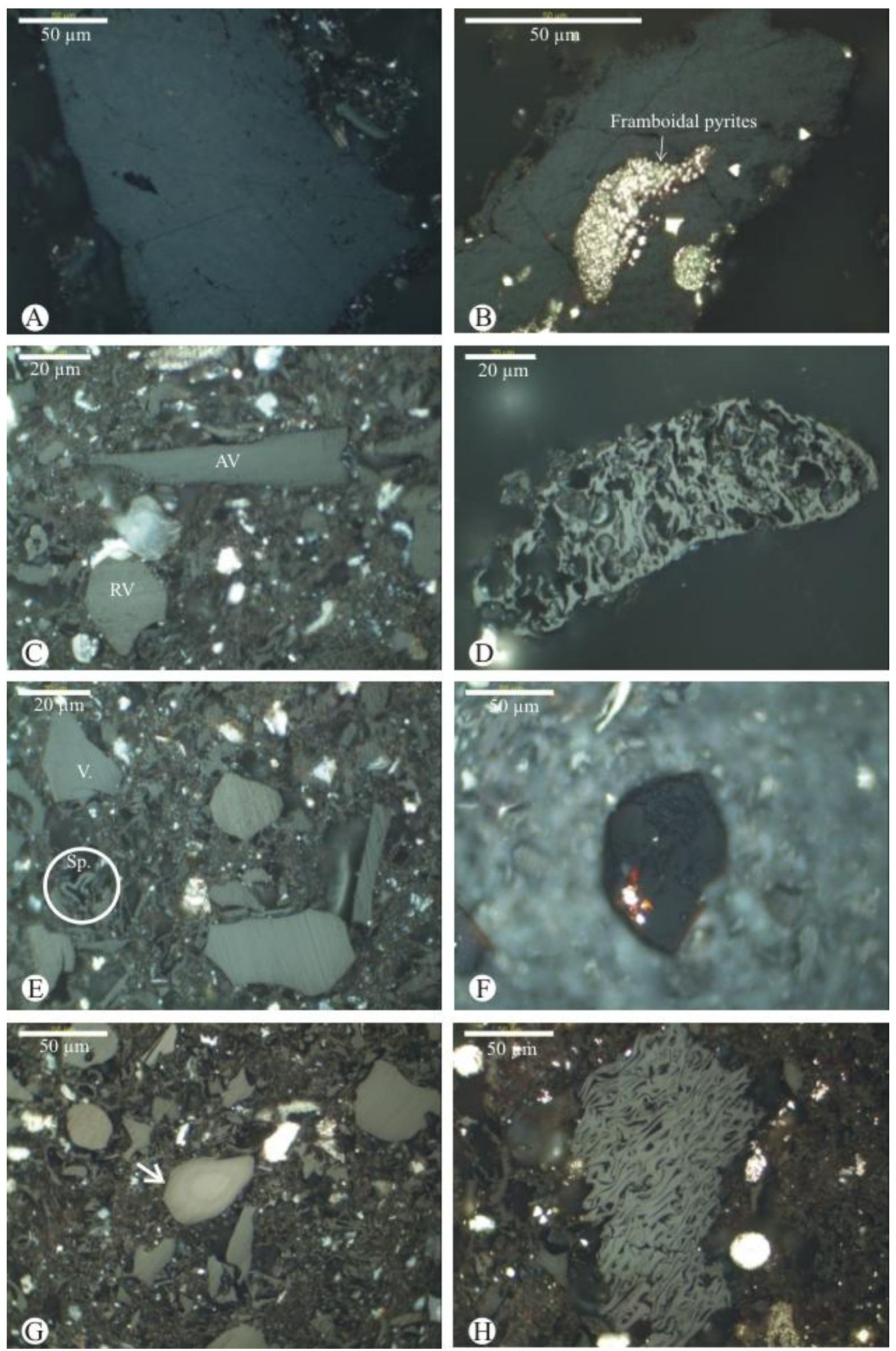

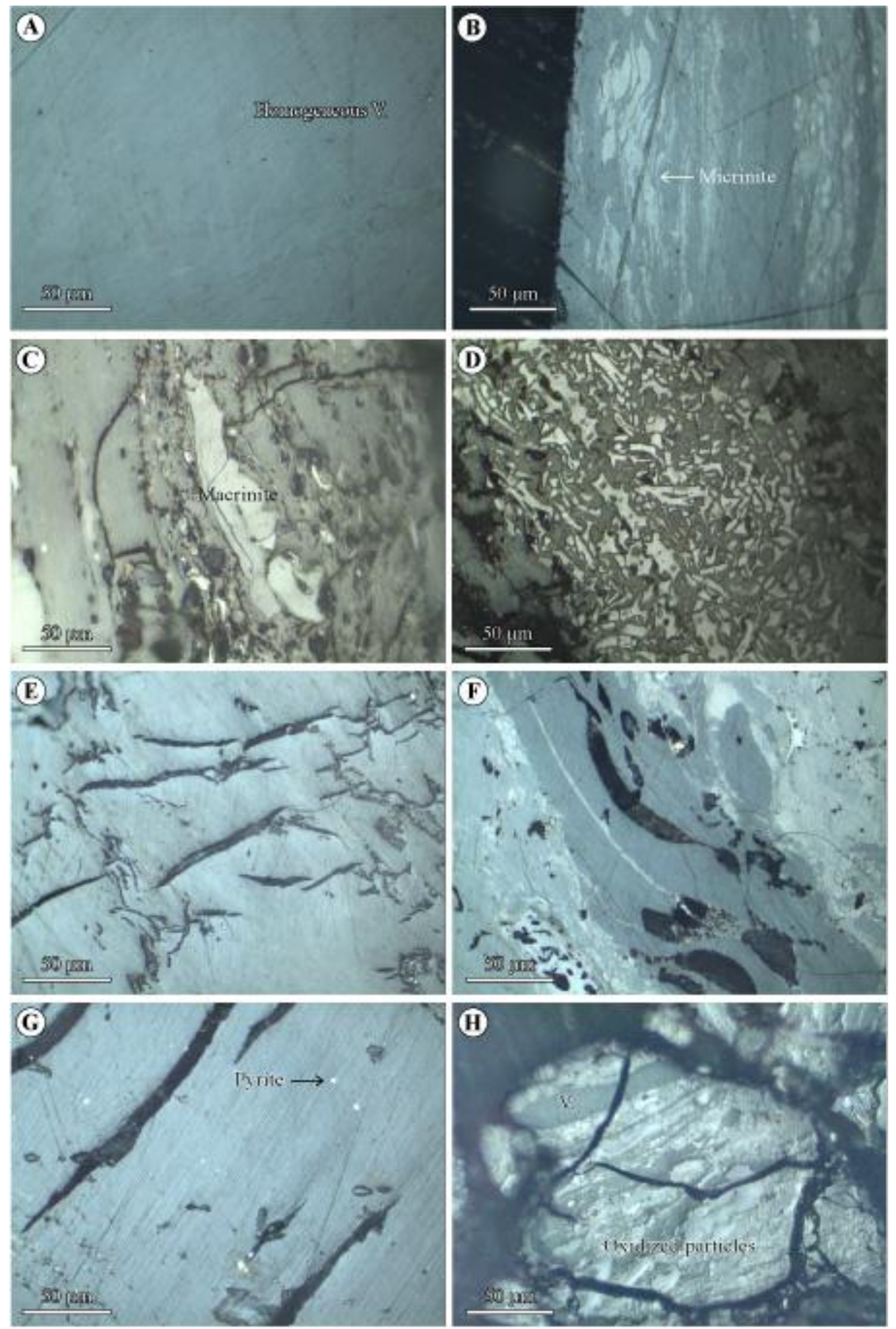


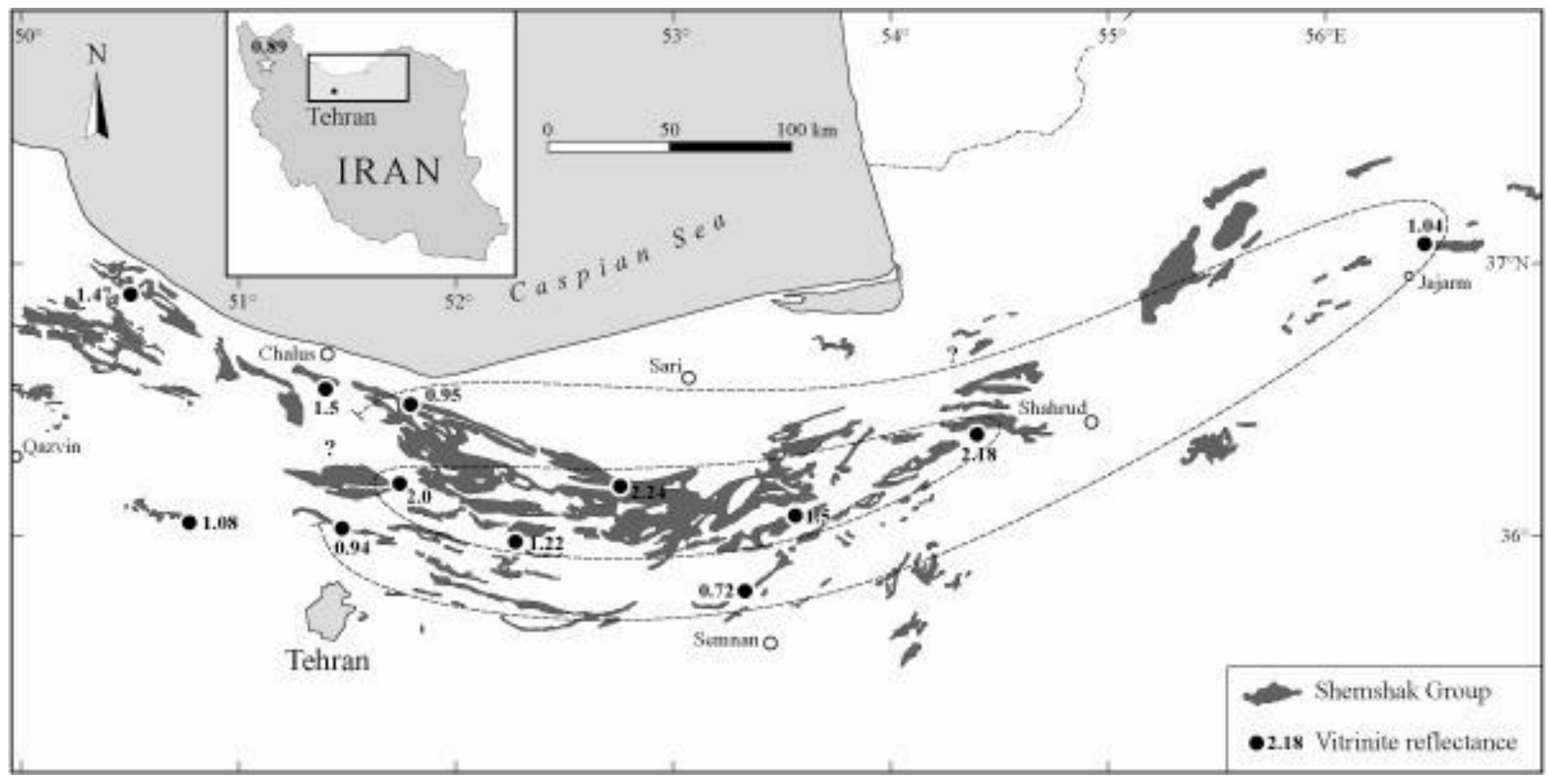

Fig. 7 

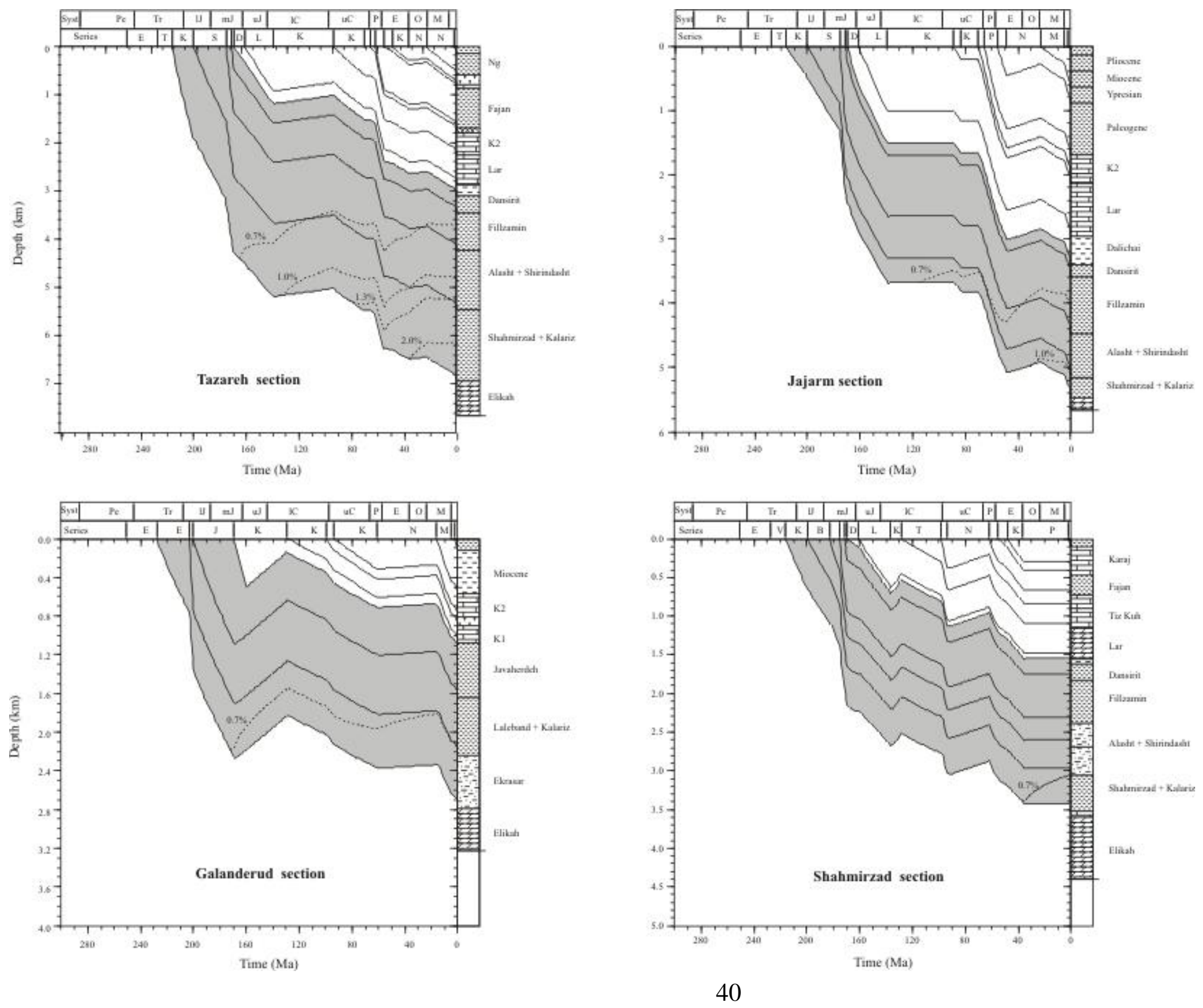

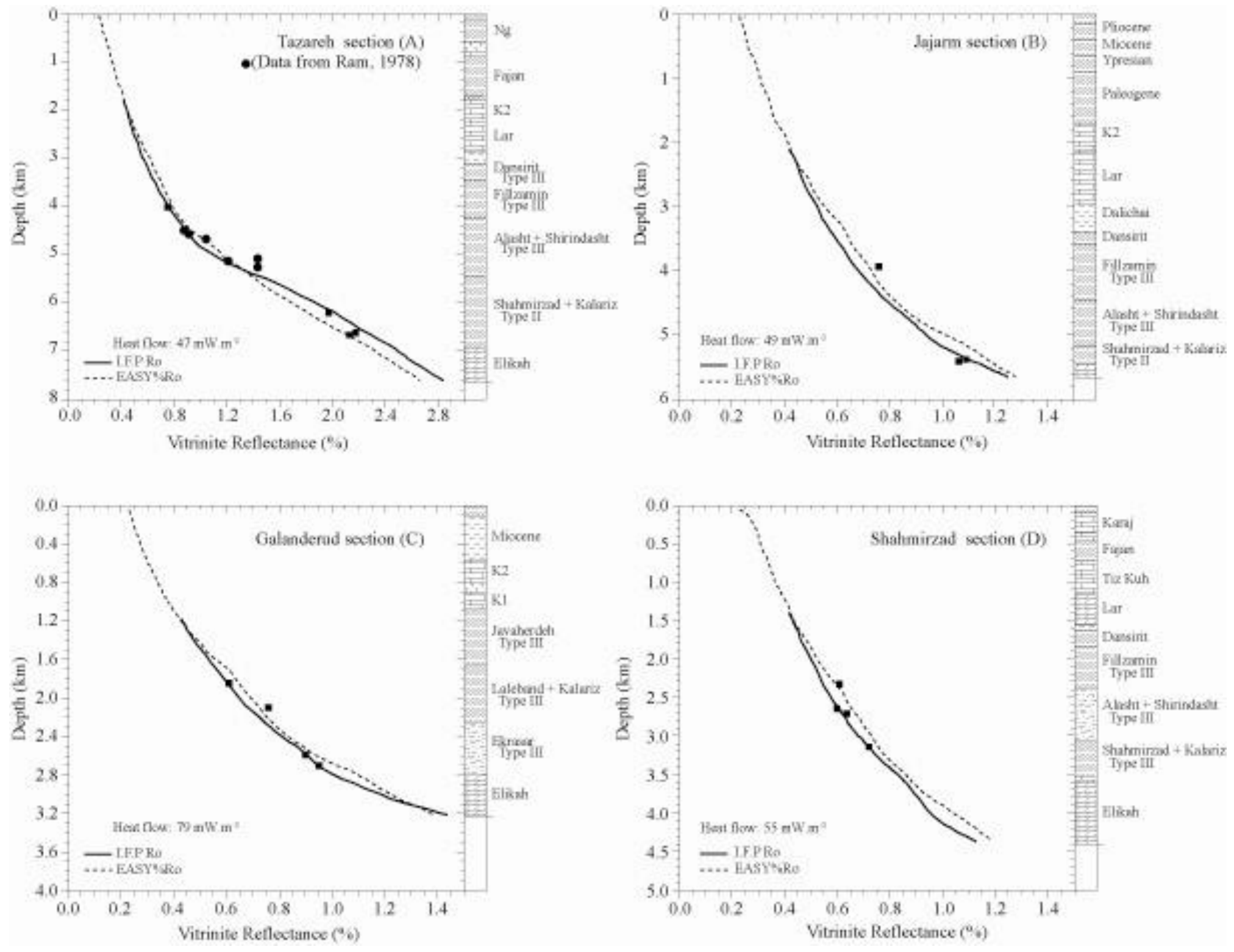

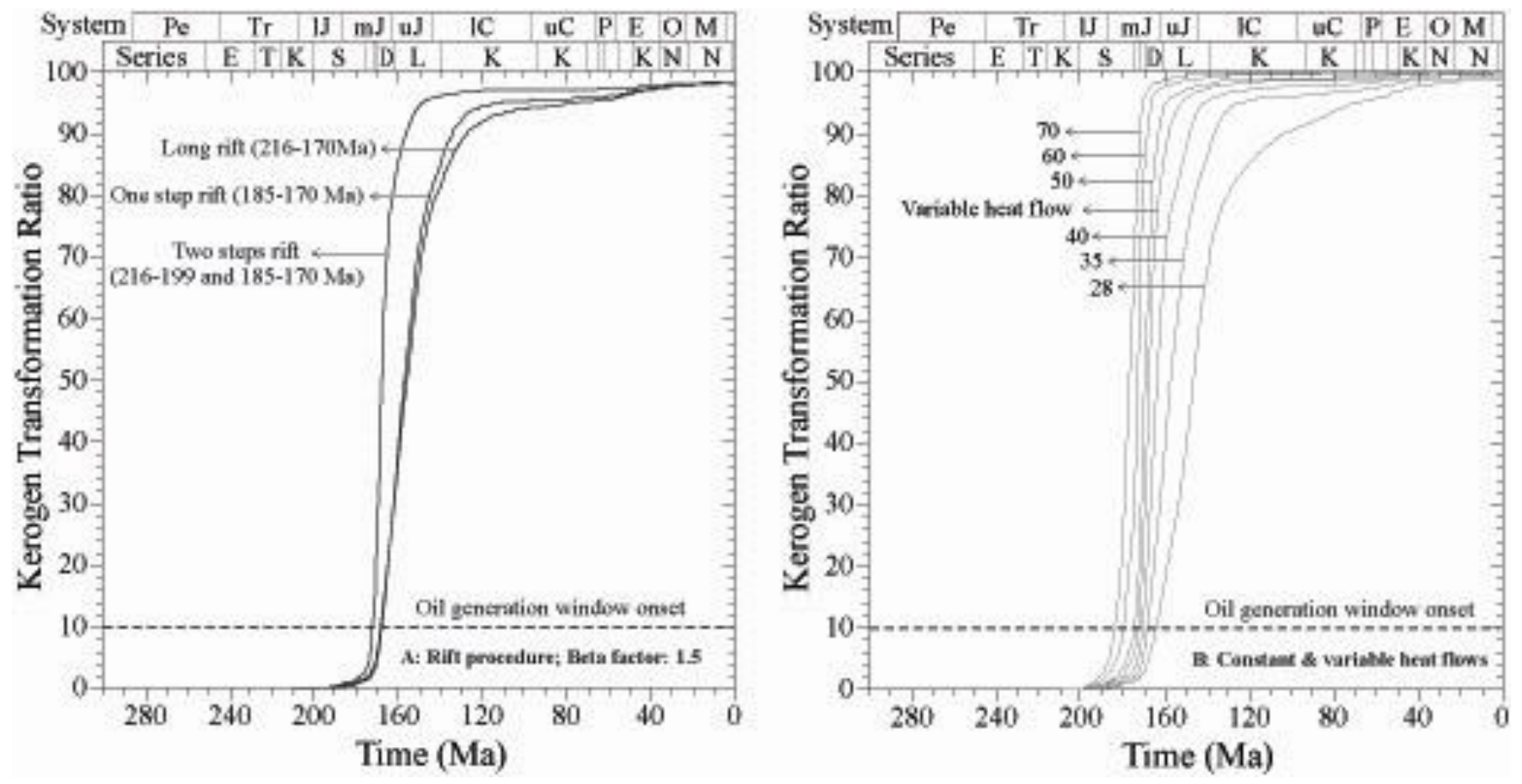

Fig. 10 


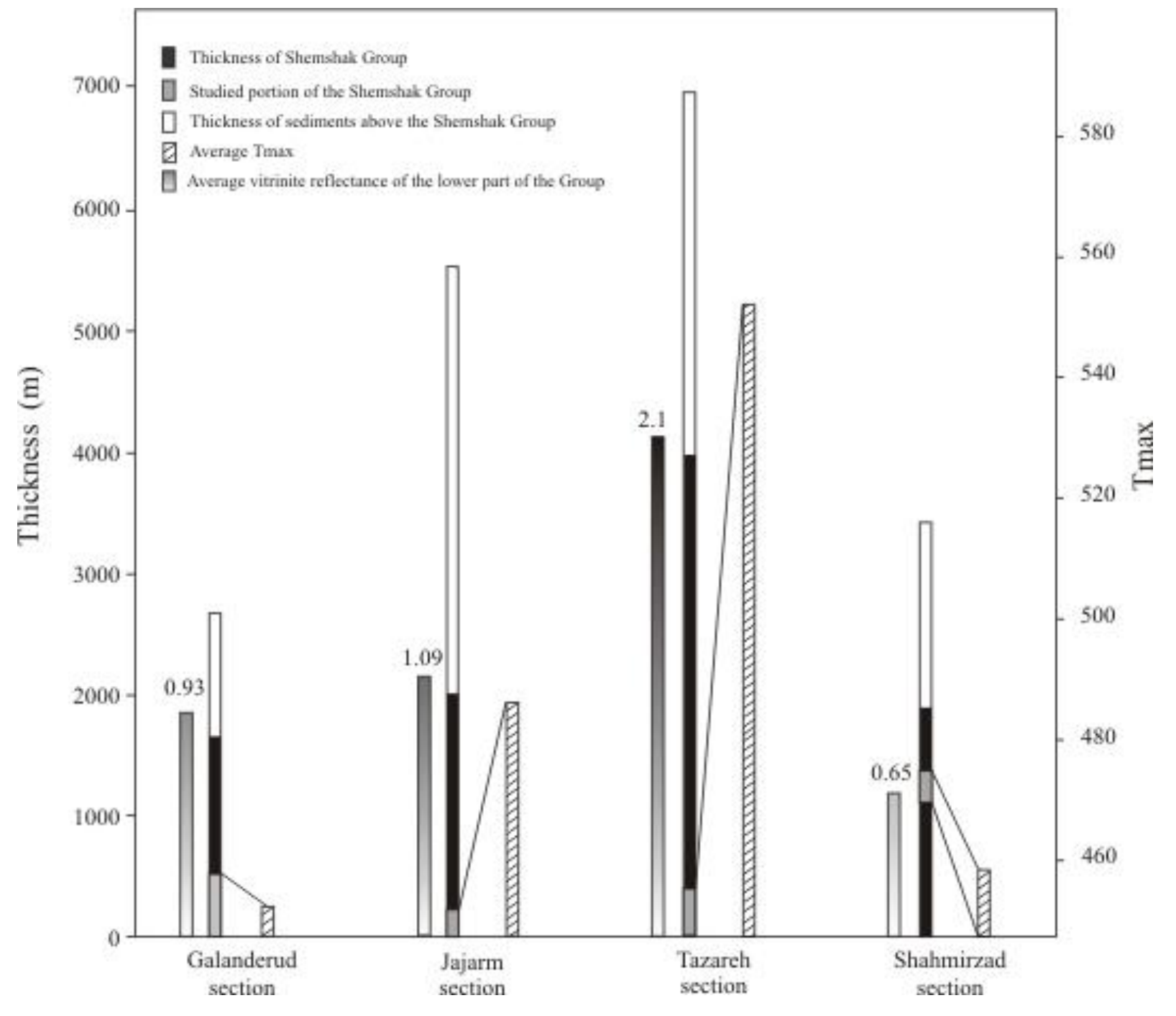

Fig. 11 


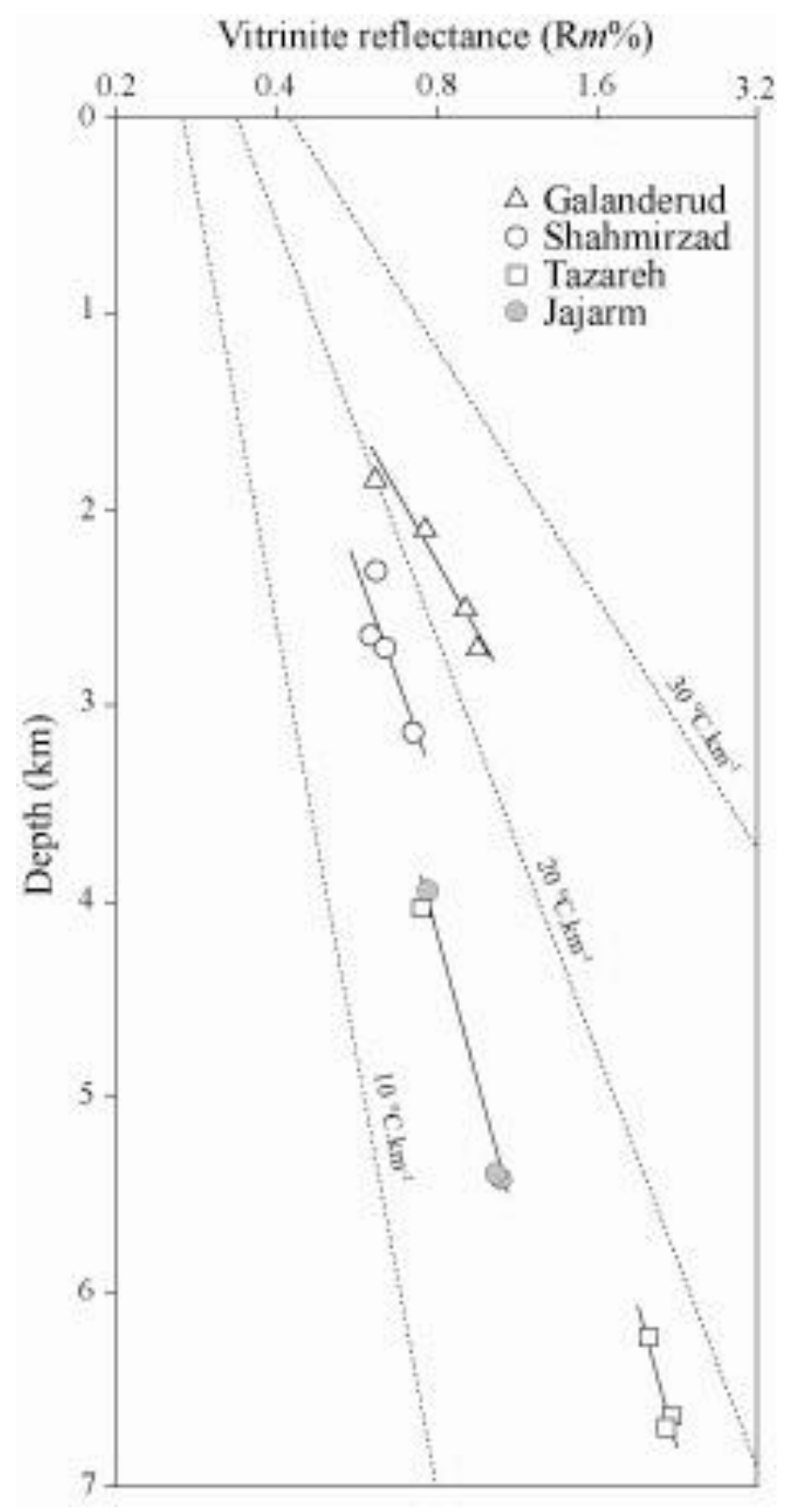

Fig. 12 


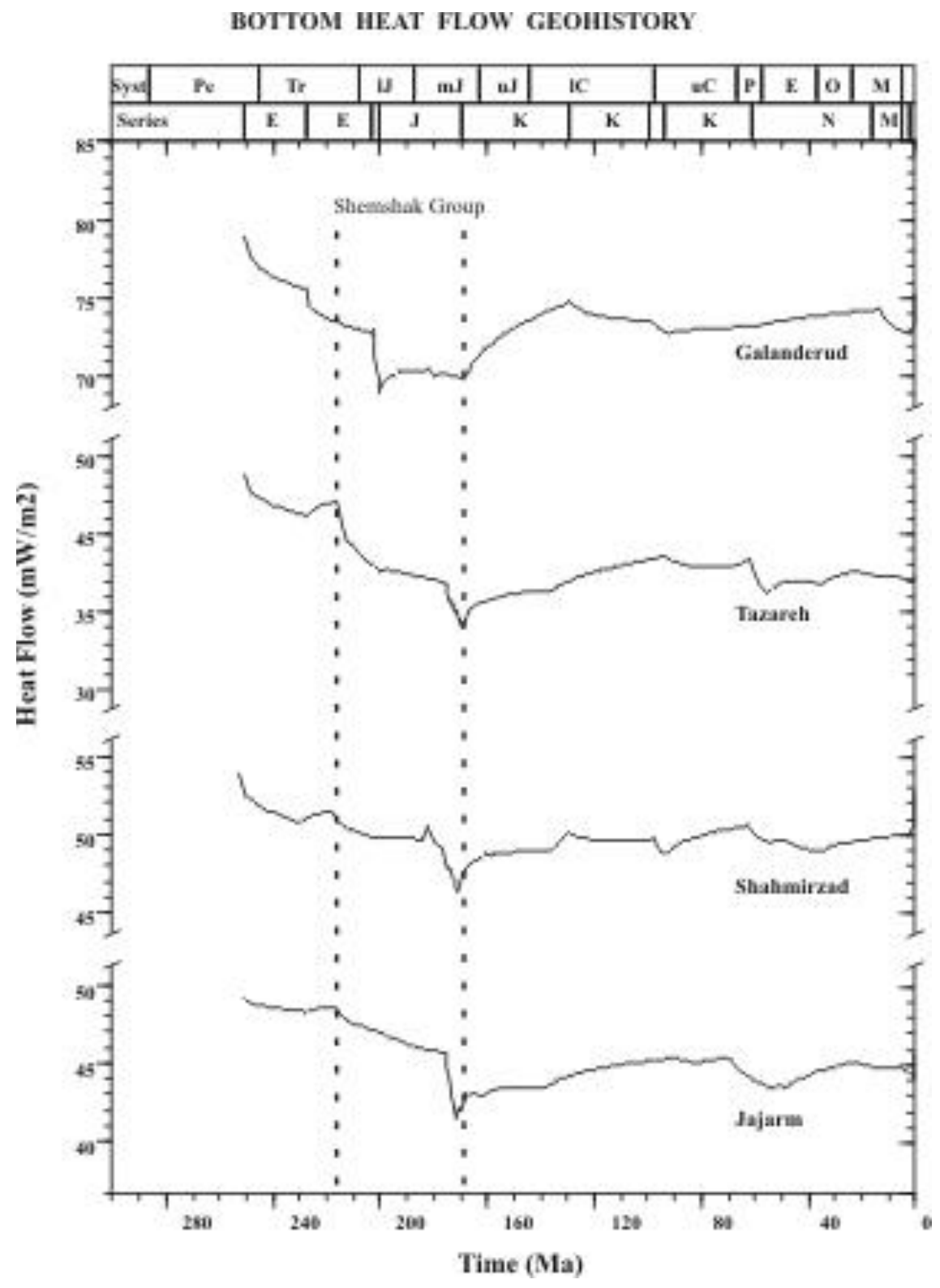

Fig. 13 


\begin{tabular}{|c|c|c|c|c|c|c|c|}
\hline $\begin{array}{l}N^{\circ} \text { as } \\
\text { figs } 1 \& 2\end{array}$ & Lecalityisectisn & Formation & $\begin{array}{l}\text { Descriptises of } \\
\text { imestigated interval (thickness) }\end{array}$ & $\begin{array}{l}\text { Number of } \\
\text { samples }\end{array}$ & $\begin{array}{c}\text { ToC } \\
\text { Min-Max } \\
\text { (Nean) }\end{array}$ & $\begin{array}{c}\text { HII } \\
\text { MEriax -MLax } \\
\text { (Mean) }\end{array}$ & $\begin{array}{c}\text { Gezctic polential } \\
\text { Min-Mlax } \\
\text { (Mean) }\end{array}$ \\
\hline \multirow{2}{*}{9} & \multirow{2}{*}{ Galanderud } & Laleband & 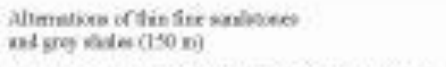 & 10 & $\begin{array}{c}0.47-1.19 \\
(0.85)\end{array}$ & (iin & $\begin{array}{l}0.0-4 s \\
(0,3)\end{array}$ \\
\hline & & Ekrasar & 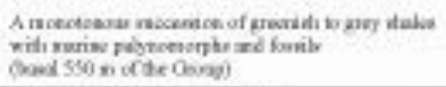 & 28 & $\frac{0+24}{(0.5)}$ & $\begin{array}{l}0.61 \\
077\end{array}$ & $\begin{array}{l}0,4 \\
014\end{array}$ \\
\hline \multirow{2}{*}{$\mathrm{s}$} & \multirow{2}{*}{ Paland } & Lalcband & 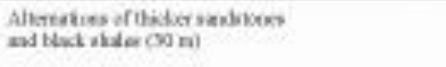 & s & 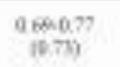 & 0 & $\begin{array}{l}002045 \\
\text { (0.03) }\end{array}$ \\
\hline & & Ekrasar & 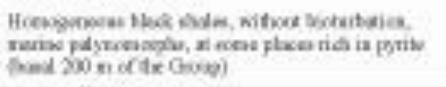 & , & $\begin{array}{l}\cos x+5 \\
{[297]}\end{array}$ & $\begin{array}{l}0.92 \\
51\end{array}$ & $\frac{0.023}{(0.1)}$ \\
\hline 10 & Ekrasar & Ekracar & 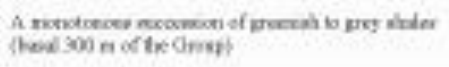 & 8 & 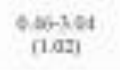 & 909 & $\begin{array}{l}\text { boseds } \\
\text { nolis }\end{array}$ \\
\hline 5 & Tazarch & Shethmirzad & 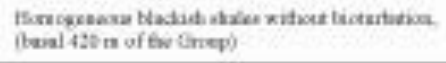 & 35 & $\begin{array}{l}0.93-x 3 \\
(1)\end{array}$ & $\begin{array}{c}4-31 \\
(5)\end{array}$ & $\begin{array}{l}0 \cos -0.4 \% \\
(0.1)\end{array}$ \\
\hline 2 & Lower Parvar & Shahmirmad & 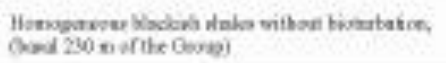 & $\Leftrightarrow$ & $\begin{array}{l}0.38-8.5 \\
\text { (1.1) }\end{array}$ & $\begin{array}{c}0-1 \\
(0,3)\end{array}$ & $\begin{array}{l}\text { oga } 16 \\
\text { aes) }\end{array}$ \\
\hline 12 & Lowser Jajarm & Shathmarzad & 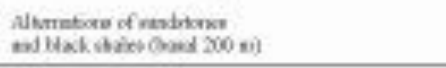 & 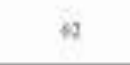 & $\begin{array}{c}4.8650 \\
\pi+46\end{array}$ & $\begin{array}{l}\text { a-16s } \\
\text { (0) }\end{array}$ & $\begin{array}{l}0.501 \\
+389\end{array}$ \\
\hline 6 & Damavand & Shothmirzad & 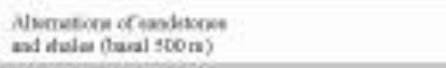 & 19 & $\begin{array}{c}0.3 .5 \\
0.58\end{array}$ & $\begin{array}{c}0-12 \\
1+.5\end{array}$ & $\operatorname{ag}_{\infty \rightarrow 3}-19$ \\
\hline 7 & Baladeh & Shsthmirzad & 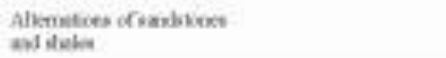 & 3 & $\begin{array}{c}0.5 \cdot 19 \\
0.09\end{array}$ & & $\begin{array}{l}0.1-09 \\
12259\end{array}$ \\
\hline
\end{tabular}

Table 1

\begin{tabular}{|c|c|c|c|c|c|c|c|}
\hline $\begin{array}{l}x^{2} \text { en } \\
\text { fige } 1 \& 2\end{array}$ & Leallybectien & Fermation & $\begin{array}{l}\text { Descriptises of } \\
\text { imvestigated interval (thickiness) }\end{array}$ & $\begin{array}{l}\text { Number of } \\
\text { camples }\end{array}$ & $\begin{array}{c}\text { TOC } \\
\text { Min-Max } \\
\text { (Mean) }\end{array}$ & $\begin{array}{c}\text { HII } \\
\text { Min-Mas } \\
\text { (Avan) }\end{array}$ & $\begin{array}{c}\text { Genctic potketial } \\
\text { Milis-Mlax } \\
\text { (Alean) }\end{array}$ \\
\hline 1 & Upper Shahmirzad & Shirindasht & 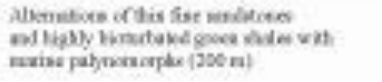 & 17 & $\begin{array}{l}0 \times 10 \\
0045\end{array}$ & $\frac{0-2 x}{015}$ & b \\
\hline$s$ & Sharif-Abad & Fillzamin & 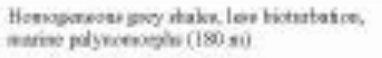 & 4 & $\begin{array}{c}0.41 .13 \\
0.831\end{array}$ & $\begin{array}{l}8-21 \\
04)\end{array}$ & $\begin{array}{l}\text { क.03-0.4 } \\
\text { (0.1) }\end{array}$ \\
\hline 6 & Damavand & Fillzamin & 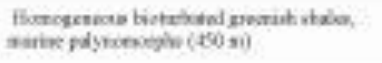 & 7 & $\begin{array}{l}05-10 \\
10,5 i\end{array}$ & (i) & $\begin{array}{l}0.02 \\
1007\end{array}$ \\
\hline 2 & Lpper Parvar & Falzsmin & 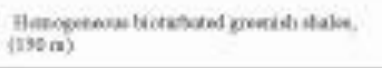 & 4 & $\begin{array}{c}0.94-073 \\
0.059\end{array}$ & 00 & b \\
\hline 13 & Shemshak type sectice & Fellzamin & 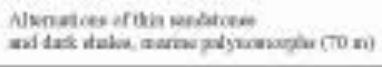 & n) & $\begin{array}{l}9007,65 \\
(10)\end{array}$ & $\begin{array}{l}40.6 \% \\
(65)\end{array}$ & $\begin{array}{l}4.33 .1 .15 \\
(0.6)\end{array}$ \\
\hline 12 & Upper Injarm & Fillzamin & 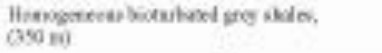 & is & $\begin{array}{l}606-1,3 \\
0.575\end{array}$ & $\begin{array}{l}2-36 \\
120\end{array}$ & $\begin{array}{c}\text { oal-a } 47 \\
\log 13\end{array}$ \\
\hline
\end{tabular}

Tahle 2 . 


\begin{tabular}{|c|c|c|c|c|c|c|}
\hline $\begin{array}{l}\mathrm{N}^{\circ} \text { on } \\
\text { figs. } 1 \& 2\end{array}$ & Lacality/sectËon & Formatiste & $\begin{array}{l}\text { Nembsr } \\
\text { of samplos }\end{array}$ & $\begin{array}{c}\text { Toc } \\
\text { Min-Mas } \\
\text { (Mena) }\end{array}$ & $\begin{array}{c}\text { HII } \\
\text { Min-Sias } \\
\text { (Niraid) }\end{array}$ & $\begin{array}{l}\text { Cenctic potential } \\
\text { Min-max } \\
\text { (Nesab) }\end{array}$ \\
\hline 1 & Shahmirzad & Kalariz. & 3 & $\begin{array}{c}30-202 \\
(50.1)\end{array}$ & $\begin{array}{l}12 \cdot 96 \\
417\end{array}$ & $\begin{array}{l}3.7-13 \\
9.13\end{array}$ \\
\hline 11 & Jsusthordets & devaherdeh & 4 & $\begin{array}{l}97.35 .1 \\
(235)\end{array}$ & (2) & $\begin{array}{l}04-13 \\
00821\end{array}$ \\
\hline tit & Hive & Kalariz: & $\theta$ & $\begin{array}{l}35846 \\
\text { [st] }\end{array}$ & $\begin{array}{l}n \cdot 190 \\
\text { (132) }\end{array}$ & $\begin{array}{c}1.4-151.8 \\
(55.4)\end{array}$ \\
\hline 6 & Damsurend & Kalariz, Dansirit & 2 & $\begin{array}{l}3.252 .4 \\
(1965)\end{array}$ & $\begin{array}{l}9.250 \\
(1275)\end{array}$ & $\begin{array}{c}a+201 \\
(100)\end{array}$ \\
\hline 15 & Maraghdh & Kalariz & 2 & $\begin{array}{c}513691 \\
6735\end{array}$ & $\frac{0-19}{(9)}$ & $\begin{array}{c}0.4-2.12 \\
0.20\end{array}$ \\
\hline
\end{tabular}

Table 3.

\begin{tabular}{|c|c|c|c|c|c|c|c|c|c|c|}
\hline Organic-rich unit & Locality & Samph & $\mathrm{C} \%$ & $\mathrm{H} \%$ & $0 \%$ & $\mathrm{~N} *$ & $\$ \%$ & Total s: & HCratio & ac ntio \\
\hline uTs & 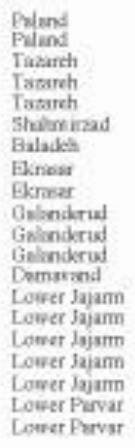 & 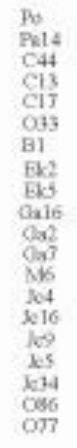 & $\begin{array}{l}54.33 \\
60.95 \\
62.92 \\
53.62 \\
56.87 \\
47.37 \\
45.56 \\
52.42 \\
69.06 \\
54.32 \\
51.39 \\
50.4 \\
62.76 \\
66.23 \\
59.95 \\
61.26 \\
63.59 \\
62.64 \\
61.52 \\
47.4\end{array}$ & $\begin{array}{l}2.15 \\
2.41 \\
2.52 \\
1.81 \\
2.07 \\
2.41 \\
1.32 \\
2.52 \\
3.27 \\
3.17 \\
2.71 \\
3.44 \\
2.37 \\
3.44 \\
2.87 \\
3.24 \\
4.13 \\
2.75 \\
2.36 \\
2.08\end{array}$ & $\begin{array}{r}1286 \\
733 \\
665 \\
754 \\
025 \\
21.47 \\
1019 \\
470 \\
452 \\
7.24 \\
671 \\
612 \\
836 \\
632 \\
6.09 \\
535 \\
352 \\
5.46 \\
18.36 \\
11.23\end{array}$ & $\begin{array}{l}093 \\
0.97 \\
1.05 \\
0.64 \\
0.84 \\
0.82 \\
0.44 \\
0.90 \\
1.23 \\
1.22 \\
1.19 \\
1.31 \\
0.34 \\
1.23 \\
1.14 \\
0.75 \\
1.08 \\
1.03 \\
1.03 \\
0.62\end{array}$ & 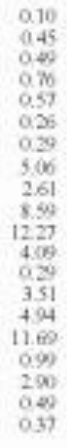 & $\begin{array}{l}7007 \\
7213 \\
73.63 \\
6437 \\
6.59 \\
7202 \\
58.39 \\
65.59 \\
80.66 \\
74.54 \\
74.27 \\
344 \\
7463 \\
8073 \\
7499 \\
82.29 \\
7931 \\
74.78 \\
83.76 \\
61.34\end{array}$ & $\begin{array}{l}0.45 \\
0.47 \\
045 \\
0.53 \\
044 \\
0.61 \\
0.34 \\
0.55 \\
055 \\
070 \\
0.63 \\
020 \\
0.45 \\
062 \\
0.57 \\
0.64 \\
073 \\
0.53 \\
045 \\
0.53\end{array}$ & $\begin{array}{l}0.17 \\
009 \\
008 \\
0.14 \\
0.12 \\
0.34 \\
0.15 \\
0.07 \\
005 \\
0.10 \\
0.10 \\
000 \\
0.10 \\
0.07 \\
0.08 \\
007 \\
0.06 \\
007 \\
0.22 \\
0.18\end{array}$ \\
\hline TAS & 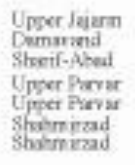 & $\begin{array}{l}\ln 14 \\
921 \\
0 \times 0 \\
008 \\
030 \\
0.55 \\
046\end{array}$ & $\begin{array}{l}39.82 \\
12.25 \\
38.46 \\
39.00 \\
44.62 \\
36.53 \\
26.37\end{array}$ & $\begin{array}{l}2.54 \\
1.75 \\
2.06 \\
1.45 \\
1.44 \\
1.57 \\
1.67\end{array}$ & $\begin{array}{l}764 \\
830 \\
958 \\
520 \\
627 \\
928 \\
9.16\end{array}$ & $\begin{array}{l}091 \\
078 \\
0.68 \\
0.61 \\
0.52 \\
0.34 \\
0.60\end{array}$ & $\begin{array}{l}056 \\
044 \\
025 \\
0.83 \\
0.49 \\
0.44 \\
0.23\end{array}$ & $\begin{array}{l}71,52 \\
53.55 \\
5106 \\
4700 \\
53.94 \\
4357 \\
40.03\end{array}$ & $\begin{array}{l}051 \\
050 \\
014 \\
045 \\
0.50 \\
069 \\
071\end{array}$ & $\begin{array}{l}0.10 \\
0.15 \\
0.19 \\
0.10 \\
0.11 \\
019 \\
0.24\end{array}$ \\
\hline $\operatorname{ccs}$ & 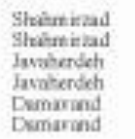 & $\begin{array}{l}0.12 \\
\text { Oshi1 } \\
\text { 14 } \\
18 \\
\text { M13 } \\
\text { M23 }\end{array}$ & $\begin{array}{l}55.77 \\
38.38 \\
78.85 \\
71.82 \\
58.4 \\
64.45\end{array}$ & $\begin{array}{l}257 \\
2.29 \\
35 \pi \\
2.66 \\
2.89 \\
3.72\end{array}$ & $\begin{array}{l}1859 \\
1322 \\
407 \\
1968 \\
1735 \\
705\end{array}$ & $\begin{array}{l}073 \\
0.53 \\
115 \\
0.95 \\
0.71 \\
0.02\end{array}$ & $\begin{array}{l}0.20 \\
024 \\
056 \\
043 \\
046 \\
0.4\end{array}$ & $\begin{array}{l}73.05 \\
4.65 \\
8.57 \\
95.53 \\
50.29 \\
70.68\end{array}$ & $\begin{array}{l}a 55 \\
a 72 \\
0.60 \\
0.44 \\
055 \\
0.06\end{array}$ & $\begin{array}{l}0.25 \\
025 \\
004 \\
0.21 \\
0.23 \\
0.08\end{array}$ \\
\hline
\end{tabular}

Table 4. 


\begin{tabular}{|c|c|c|c|c|c|}
\hline$N^{0}$ os figs. $1 \leqslant 2$ & Section ositcrop & Number of sample & Number of sample & Ams 6 (trange) & $R \mathrm{~m}^{\mathrm{n}}$ "s(avarugs) \\
\hline 5 & Tazareh & 7 & 4 & $0.75-2.18$ & 1.76 \\
\hline 8 & Paland & 4 & 2 & $1.0-2.24$ & 162 \\
\hline$T$ & Baladeh & - & 1 & 2 & 2.00 \\
\hline 6 & Damavaed & 3 & 3 & $0.83-1.22$ & 1.05 \\
\hline 2 & Parvar & - & 2 & $0.85-1.5$ & 1.18 \\
\hline 12 & Jajarm & 23 & 3 & $0.76-1.04$ & 0.94 \\
\hline 9 & Galandenad & 16 & 4 & $0.61-0.95$ & 0.81 \\
\hline 10 & Eknasar & 5 & 1 & 1.5 & 1.50 \\
\hline 11 & Javaherdeh & 7 & 2 & $1.1-1.47$ & 129 \\
\hline 14 & Hive & 9 & 4 & $0.9-1.17$ & 108 \\
\hline 1 & Shahmirzad & 7 & 4 & $0.61-0.72$ & 0.65 \\
\hline 3 & Sharif-Abad & 2 & 1 & 063 & 0.63 \\
\hline 13 & Shemshak type locality & 10 & 4 & $0.78-094$ & 0.83 \\
\hline 15 & Maragheh & 2 & 2 & $0.88-0.89$ & 0.88 \\
\hline
\end{tabular}

Table 5 , 